\title{
The enigmatic curvature of Central Iberia and its puzzling kinematics
}

\author{
Daniel Pastor-Galán ${ }^{1,2,3, \text { o }}$, Gabriel Gutiérrez-Alonso ${ }^{4,5}$, and Arlo B. Weil ${ }^{6}$ \\ ${ }^{1}$ Frontier Research Institute for Interdisciplinary Sciences, Tohoku University, 41 Kawauchi, Aoba-ku, \\ Sendai, Miyagi 980-8576, Japan \\ ${ }^{2}$ Department of Earth Science, Tohoku University, 41 Kawauchi, Aoba-ku, Sendai, Miyagi 980-8576, Japan \\ ${ }^{3}$ Center for Northeast Asian Studies, Tohoku University, 41 Kawauchi, Aoba-ku, Sendai, Miyagi 980-8576, Japan \\ ${ }^{4}$ Dept. of Geology, Faculty of Sciences, University of Salamanca, Plaza de la Merced s/n, Salamanca 38007, Spain \\ ${ }^{5}$ Geology and Geography Department, Tomsk State University, Lenin Street 36, Tomsk 634050, Russia \\ ${ }^{6}$ Department of Geology, Bryn Mawr College, Bryn Mawr, PA 19010, USA \\ 을ited contribution by Daniel Pastor-Galán, recipient of the EGU Tectonics and Structural Geology Division Outstanding \\ Early Career Scientists Award 2019.
}

Correspondence: Daniel Pastor-Galán (pastor.galan.daniel.a8@ tohoku.ac.jp)

Received: 10 April 2020 - Discussion started: 16 April 2020

Revised: 30 May 2020 - Accepted: 10 June 2020 - Published: 8 July 2020

\begin{abstract}
The collision between Gondwana and Laurussia that formed the latest supercontinent, Pangea, occurred during Devonian to early Permian times and resulted in a largescale orogeny that today transects Europe, northwest Africa, and eastern North America. This orogen is characterized by an "S" shaped corrugated geometry in Iberia. The northern curve of the corrugation is the well-known and studied Cantabrian (or Ibero-Armorican) Orocline and is convex to the east and towards the hinterland. Largely ignored for decades, the geometry and kinematics of the southern curvature, known as the Central Iberian curve, are still ambiguous and hotly debated. Despite the paucity of data, the enigmatic Central Iberian curvature has inspired a variety of kinematic models that attempt to explain its formation but with little consensus. This paper presents the advances and milestones in our understanding of the geometry and kinematics of the Central Iberian curve from the last decade with particular attention to structural and paleomagnetic studies.

When combined, the currently available datasets suggest that the Central Iberian curve did not undergo regional differential vertical-axis rotations during or after the latest stages of the Variscan orogeny and did not form as the consequence of a single process. Instead, its core is likely a primary curve (i.e., inherited from previous physiographic features of the Iberian crust), whereas the curvature in areas outside the
\end{abstract}

core is dominated by folding interference from the Variscan orogeny or more recent Cenozoic (Alpine) tectonic events.

\section{Introduction}

Mountain belt systems are the most striking product of plate tectonics. In addition to their astonishing visual impact, marking the locations where ancient and modern plates collided, orogenic belts often preserve a variety of rocks that have the potential to illuminate the entirety of the system's pre- and synorogenic histories. One of the striking characteristics of most of Earth's orogens is their curvature in plan view (e.g., van der Voo, 2004; Marshak, 2004; Rosenbaum, 2014). The degree of orogenic curvature may range from a few degrees of deflection in structural trend (e.g., Kopet Dag, Iran) to $180^{\circ}$ of arc curvature (e.g., Kazakhstan arc and the Carpathians). The kinematic, structural, and geodynamic implications of these systems are as varied as their geometries (Marshak, 2004; Weil and Sussman, 2004; Johnston et al., 2013). For example, some orogenic curvatures are hypothesized to be the consequence of physiographic features of the basement that predate orogen formation, such as irregular basin architectures or plate margin salients and recesses that formed from rift-to-drift processes (e.g., Jura mountains; 
Hindle et al., 2000), which then control the growth geometry of the ensuing orogen. These systems are known as primary arcs which reflect pre-orogenic geometries and show no significant or systematic vertical-axis rotations along their structural length. On the other hand, oroclines, as classically defined by Carey (1955), involve systematic differential vertical-axis rotations subsequent to initial orogenic shortening; different sectors of an orogen rotate with variable magnitudes or in opposite directions (e.g., Li et al., 2012). Rotations in oroclines may occur at a range of scales from thrust emplacement at upper crustal levels (e.g., Izquierdo-Llavall et al., 2018) up to lithospheric-scale vertical-axis folding (e.g., Li et al., 2018). They can occur as single curves (e.g., Maffione et al., 2009), coupled curves (Johnston, 2001), or in trains of curves (Li and Rosenbaum, 2014). Oroclines can form during the main orogenic building event, known as progressive oroclines (e.g., the Wyoming salient; Yonkee and Weil, 2010; Weil et al., 2010a), or during a subsequent tectonic pulse, so-called secondary oroclines (Weil and Sussman, 2004; Johnston et al., 2013). Unraveling the kinematics and mechanisms of curvature formation in mountain belts is a critical step to understand orogenesis in $4 \mathrm{D}$ and to evaluate their geodynamic consequences and paleogeographic implications.

The Variscan-Alleghanian orogeny resulted in the suturing of Gondwana and Laurussia during DevonianCarboniferous times and ultimately led to the formation of the supercontinent, Pangea. This long and sinuous orogen runs for $>8000 \mathrm{~km}$ along strike and is ca. $1000 \mathrm{~km}$ wide, transecting through Europe to northwest Africa and into eastern North America. The final stages of Pangea's amalgamation (e.g., Nance et al., 2010) modified the western European sector of the belt into its characteristic sinuous shape. Today, this tectonic belt traces at least one and perhaps four arcs from Poland to Brittany and then across the Bay of Biscay (Cantabrian Sea) into Iberia, where the system is truncated by the younger Betic-Alpine orogeny in southeast Iberia (Fig. 1; e.g., Weil et al., 2013). The southern truncation of the Variscan in Europe hinders a precise correlation with equivalent age outcrops in NW Africa.

Within the Iberian Peninsula, the orogen is characterized by two large-scale curves (Fig. 2): (1) to the north is the wellstudied and nearly $180^{\circ}$ secondary orocline, the Cantabrian (a.k.a. Ibero-Armorican) Orocline, which buckled a segment of the Variscan belt from $\sim 315$ to $\sim 290 \mathrm{Ma}$ (e.g., Weil et al., 2019, and references therein); and (2) to the south is a curve with disputed magnitude and kinematics that is usually referred to as the Central Iberian curve or orocline or Castilian bend (Martínez Catalán et al., 2015). Though there remains tremendous uncertainty of the geometry and kinematics of the Central Iberian curve, multiple hypotheses exist as to its nature, and disagreements continue on its importance in the tectonic evolution of Europe during the waning stages of Paleozoic global supercontinent construction. The diversity of interpretations of the Central Iberian curve range from a

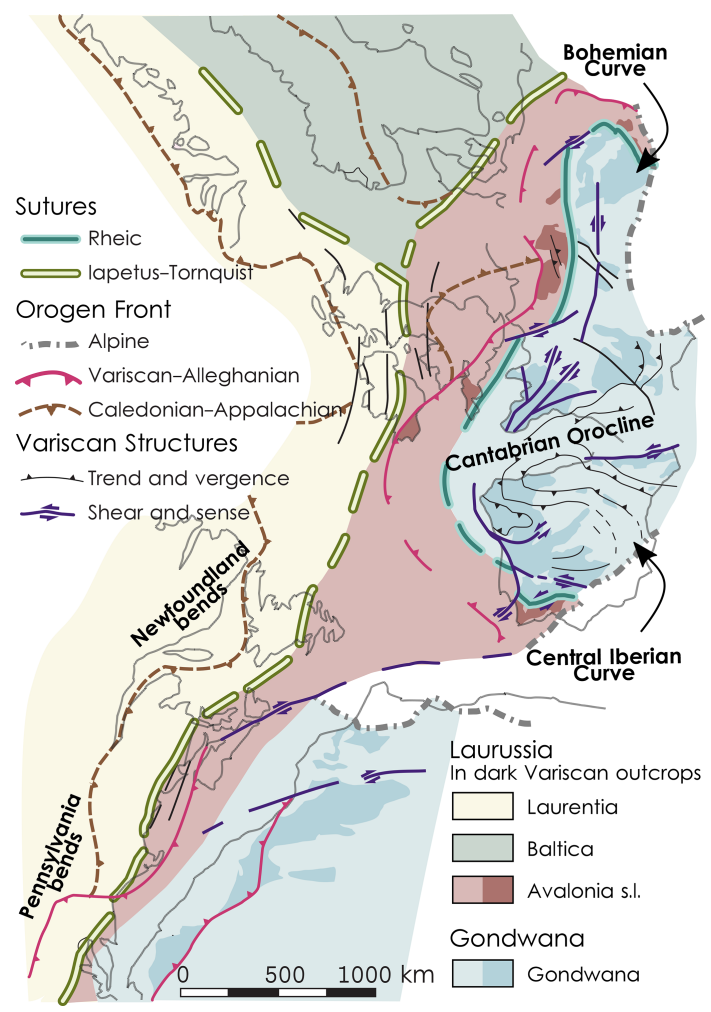

Figure 1. Simplified paleogeographic map of the VariscanAlleghanian orogeny prior to the Jurassic breakup of Pangea, with the major orogenic curves labeled. Note, this map represents Iberian outcrops without taking into account post-Jurassic Alpine deformation (see text for details; e.g., Gong et al., 2008; Pastor-Galán et al., 2018). Slightly darker colors in the Variscan belt indicate present-day European and African outcrops (modified from Martínez Catalán et al., 2009; Weil et al., 2013).

nonexistent structure (Dias et al., 2016) to its being one of the most important pieces in our understanding of the late Carboniferous and Permian geodynamics of the Iberian Variscan system (e.g., Martínez Catalán, 2011; Martínez Catalán et al., 2014).

This paper reviews the most recent advances on the geometry and kinematics of the Central Iberian curve, synthesizing what we know and what we do not, and ends with a discussion of the main unsolved issues. We hope that this paper fosters novel studies that will lead to a better understanding of when and which mechanisms were active in the aftermath of the Variscan-Alleghanian orogeny.

\section{The long and winding orogen}

The Variscan-Alleghanian (Europe-NW Africa and North America, respectively) orogeny is a continental-scale tectonic system $(1000 \mathrm{~km}$ wide and $>8000 \mathrm{~km}$ long $)$ that sutured Gondwana and Laurussia together, forming the supercontinent Pangea (e.g., Domeier and Torsvik, 2014; Edel et 


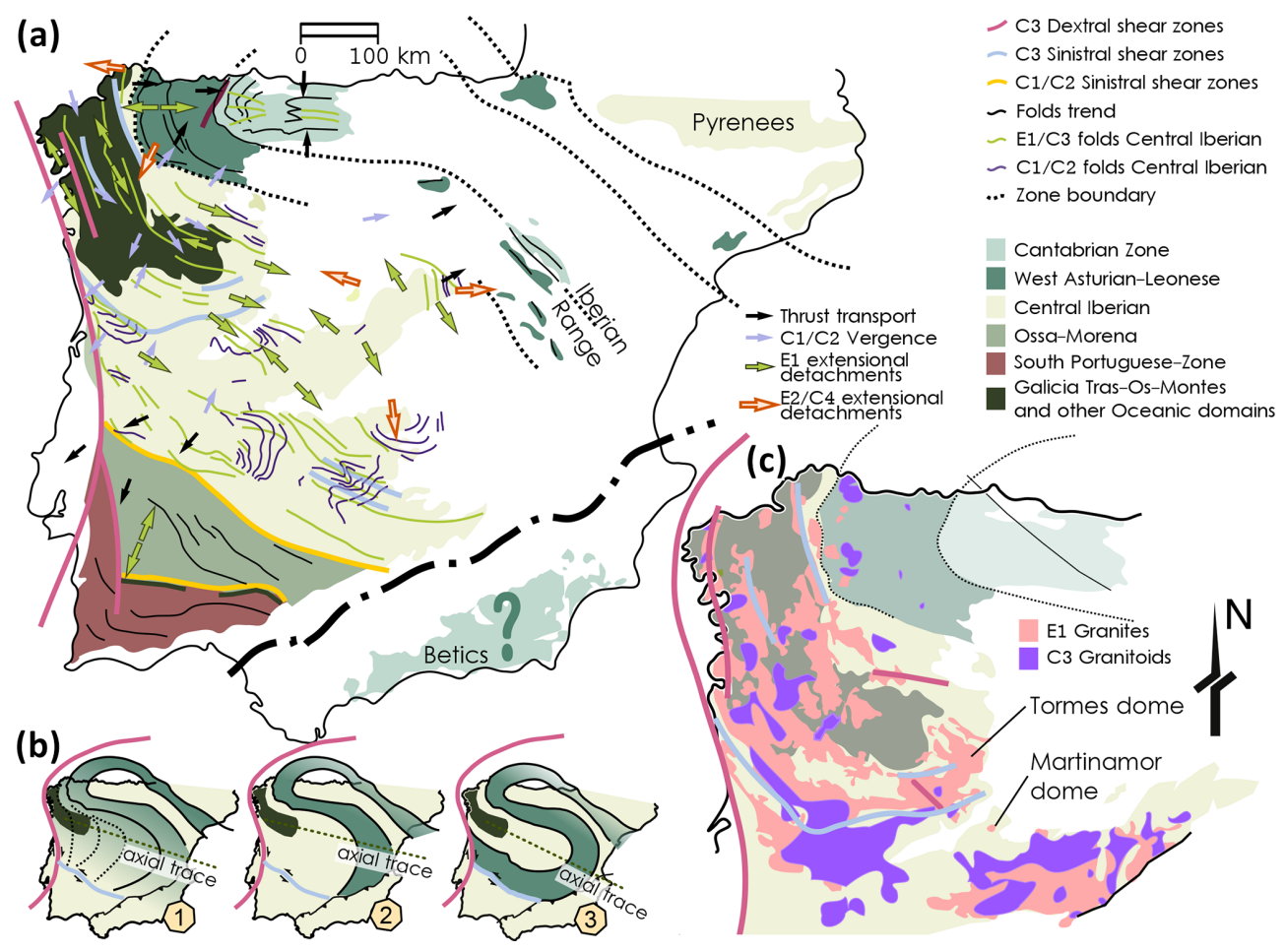

Figure 2. (a) Present-day configuration of the tectonostratigraphic zones of the Iberian Variscides and their major structures. White areas represent Mesozoic and Cenozoic cover. (b) Three competing geometric proposals for the Central Iberian curve: (1) a disharmonic curvature up to $160^{\circ}$ at the outer arc but much less pronounced at the inner arc (Aerden, 2004); (2) a harmonic but more open curvature as suggested by Martínez Catalán (2012); (3) an isoclinal curvature model (Shaw et al., 2012). (c) Distribution of the E1 (migmatitic domes) and C3 to post-C3 granitoids in the NW of Iberia (modified from Pastor-Galán et al., 2016).

al., 2018; Pastor-Galán et al., 2019a). The fragments of this system are now dispersed over three continents - Europe, Africa, and North America - due to the Mesozoic breakup of Pangea (Buiter and Torsvik, 2014; Keppie, 2016). This orogen formed as a consequence of a long and protracted tectonic history that involved several events from initial convergence (ca. 420 Ma; e.g., Franke et al., 2017) to the consumption of multiple putative oceanic tracts and/or basins that existed between Gondwana and Laurussia (ca. $280 \mathrm{Ma}$; e.g., Kirsch et al., 2012). The Variscan-Alleghanian orogen itself represents the closing of at least one major ocean, the Rheic (e.g., Nance et al., 2010), whose axial ridge likely failed or subducted at ca. $395 \mathrm{Ma}$ along its paleo-northern margin (e.g., Woodcock et al., 2007; Gutiérrez-Alonso et al., 2008a). Perhaps the orogeny involved other large oceans (Stampfli and Borel, 2002; Franke et al., 2017, 2020), but it most surely involved several minor seaways and basins that existed between Gondwana, Laurussia, and several intervening microcontinents (e.g., Azor et al., 2008; Dallmeyer et al., 1997; Kroner and Romer, 2013; Díez-Fernández et al., 2016; Pérez-Cáceres et al., 2017). The final continent-continent collision began after the closure of all oceans and intervening seaways. The commencement of this deformation was diachronistic and became progressively younger westwards (in present-day coordinates) with Devonian continent-continent collisions along the eastern boundary, progressing to the earliest Permian ages in the westernmost sector (McWilliams et al., 2013; Chopin et al., 2014; López-Carmona et al., 2014; Franke et al., 2017).

The present-day geometry of the Variscan-Alleghanian systems has a contorted trace (Fig. 1). In Europe, from east to west, the trend starts with a prominent curve around the Bohemian massif (e.g., Tait et al., 1996), followed by a deflection in the Ardennes-Bravant (e.g., Zegers et al., 2003). In Brittany, the outer curvature of the Cantabrian or IberoArmorican Orocline begins (e.g., van der Voo et al., 1997) and wraps nearly $180^{\circ}$ around and across the Bay of Biscay as it turns into northwest Iberia. The Central Iberian curve marks the final concave to the west curve (in present-day coordinates) and is the focus of this paper (e.g., Aerden, 2004; Martínez Catalán, 2011; Shaw et al., 2012). The orogen continues in North America where, from north to south, it has salients and recesses that undulate back and forth from Atlantic Maritime Canada (e.g., O'Brien and van der Pluijm, 2012) down along the Pennsylvanian curve and into the Alabama curve (e.g., Thomas, 1977).

The interpretation of the origin of these curvatures varies widely. The curvatures in North America are argued to be 
the result of a preexisting irregular margin of Laurentia due to the breakup of the Rodinia supercontinent, which resulted in the formation of orogenic salients and recesses during the subsequent Appalachian collision (e.g., Rankin, 1976; Thomas, 1977, 2004). In this case, vertical-axis rotations affected mainly the upper crustal levels during orogenesis (e.g., Marshak, 1988; Bayona et al., 2003; Hnat and van der Pluijm, 2011). In Europe, the Bohemian and ArdennesBravant massif curvatures have poor kinematic constraints. In the Bohemian Massif, some suggest secondary rotations formed an orocline (Tait et al., 1996), while others suggest little to no vertical-axis rotations or a primary arc (Chopin et al., 2012). The Ardennes-Bravant Massif recorded some vertical-axis rotations (e.g., Molina-Garza and Zeijderveld, 1996), but it is unclear if these are a response to progressive or secondary oroclinal bending or whether rotations only affected the upper crust. The most outstanding example of Variscan-Alleghanian orogen curvature is exposed in the Iberian Massif with the Cantabrian Orocline and the coupled curvature of Central Iberia.

\subsection{Two of us: the Variscan orogen in Iberia}

The western half of the Iberian Peninsula constitutes the Iberian massif, one of the largest exposures of the Variscan orogen and the only place that contains an almost continuous cross section of the orogen (Fig. 2; e.g., Lotze, 1945; Julivert et al., 1974; Pérez-Estaún et al., 1991; Ayarza et al., 1998; Simancas et al., 2003; Ribeiro et al., 2007; Martínez Catalán et al., 2014, 2019). The majority of the Iberian Massif contains Gondwanan affinity rocks (e.g., Murphy et al., 2008; Pastor-Galán et al., 2013a; Gutiérrez-Marco et al., 2017) and likely represents a proximal piece of the Gondwana margin until its final amalgamation with Pangea (e.g., PastorGalán et al., 2013b). Owing to the stratigraphic, structural, and petrological styles, the Iberian Massif has been traditionally divided into six tectonostratigraphic zones (Fig. 2; Lotze, 1945; Julivert, 1971). (1) The Cantabrian Zone represents a Gondwanan thin-skinned foreland fold-and-thrust belt. It has overall low-grade internal deformation and metamorphism and represents the shortening that occurred during Mississippian times (e.g., Marcos and Pulgar, 1982; Pérez Estaún et al., 1988; Gutiérrez-Alonso, 1996; Alonso et al., 2009; Pastor-Galán et al., 2009, 2013b). (2) The West AsturianLeonese Zone represents a metamorphic fold-and-thrust belt with Barrovian metamorphism that collapsed coevally with thrust emplacement onto the Cantabrian Zone (e.g., Martínez Catalán et al., 1992, 2014; Alcock et al., 2009). (3) The Central Iberian Zone represents the Gondwanan hinterland with Barrovian and Buchan metamorphisms and is intruded by igneous rocks of various ages (e.g., Macaya et al., 1991; Díez Balda et al., 1995; Gutiérrez-Alonso et al., 2018). (4) The Ossa-Morena Zone represents the most distal zone of the Gondwana platform and is characterized by a metamorphic fold-and-thrust belt with dominantly sinistral displacement (e.g., Robardet and Marco, 2004; Quesada, 2006). (5) The Galicia-Tras-os-Montes Zone represents a far-traveled allochthonous terrane that contains high-pressure units and relicts of oceanic-like crust (e.g., López-Carmona et al., 2014; Martínez Catalán et al., 2019). (6) The South Portuguese Zone represents a foreland fold-and-thrust belt with little internal deformation and metamorphism with Avalonian affinity and a strong sinistral component of shear (e.g., Pereira et al., 2012; Pérez-Cáceres et al., 2016; Oliveira et al., 2019a). Geographically, the external zones of the Gondwana margin are nested to the north into the core of the Cantabrian Orocline, whereas the hinterland zones are to the west and center of the massif (Fig. 2; e.g., Díaz Balda et al., 1995; Azor et al., 2019). The southwestern-most extent of Iberia contains a putative suture of the Rheic Ocean, as well as a piece of the Laurussian margin fold-and-thrust belt, which is today preserved in the South Portuguese Zone (e.g., Pereira et al., 2012, 2017; Oliveira et al., 2019a).

The Gondwanan autochthonous stratigraphy (Cantabrian, West Asturian-Leonese, Central Iberian, and Ossa-Morena zones) consists of a Neoproterozoic arc and back-arc basin (e.g., Fernández-Suárez et al., 2014), which evolved to a rift-to-drift Cambrian to early Ordovician sequence and then to an Ordovician to late Devonian passive margin basin sequence (e.g., Sánchez-García et al., 2019; Gutiérrez-Marco et al., 2019; Gutiérrez-Alonso et al., 2020). Overall the system transitioned from a relatively isolated early Cambrian continental basin to a restricted marine basin and to the development of an open marine platform that was locally punctuated by magmatism (e.g., Gutiérrez-Alonso et al., 2008b; Palero-Fernández, 2015). The Ossa-Morena Zone represents the outermost platform, followed by an intermediate platform characterized by an asymmetric horst (Central Iberian Zone) and graben (West Asturian-Leonese Zone), which ends in the innermost shelf environment of the Cantabrian Zone (Fig. 3; e.g., Gutiérrez-Marco et al., 2019). The differences between the West Asturian-Leonese and Central Iberian zones are mainly deeper versus shallower sedimentary facies (respectively) and a local Lower Ordovician unconformity in the Central Iberian Zone (Toledanian; e.g., Álvaro et al., 2018), which places Lower Ordovician strata atop pre-Cambrian to Cambrian rocks (Fig. 3; e.g., Gutiérrez-Marco et al., 2019). The Central Iberian Zone is divided into two domains: (1) the Ollo de Sapo domain, which contains abundant lower Ordovician magmatism of calc-alkaline affinity (e.g., Montes, 2007; Gutiérrez-Marco et al., 2019); and (2) the "SchistoseGreywacke domain" characterized by a predominance of outcrops of Neoproterozoic to lower Cambrian sedimentary rocks (e.g., Gutiérrez-Marco et al., 2019, and references therein).

The Galicia-Tras-os-Montes Zone (Farias et al., 1987) is a complex structural stack including a basal schistose unit (parautochthonous; Dias da Silva et al., 2020) structurally overlain by mafic rocks with an oceanic-like signature and other allochthonous rocks under high-pressure metamor- 


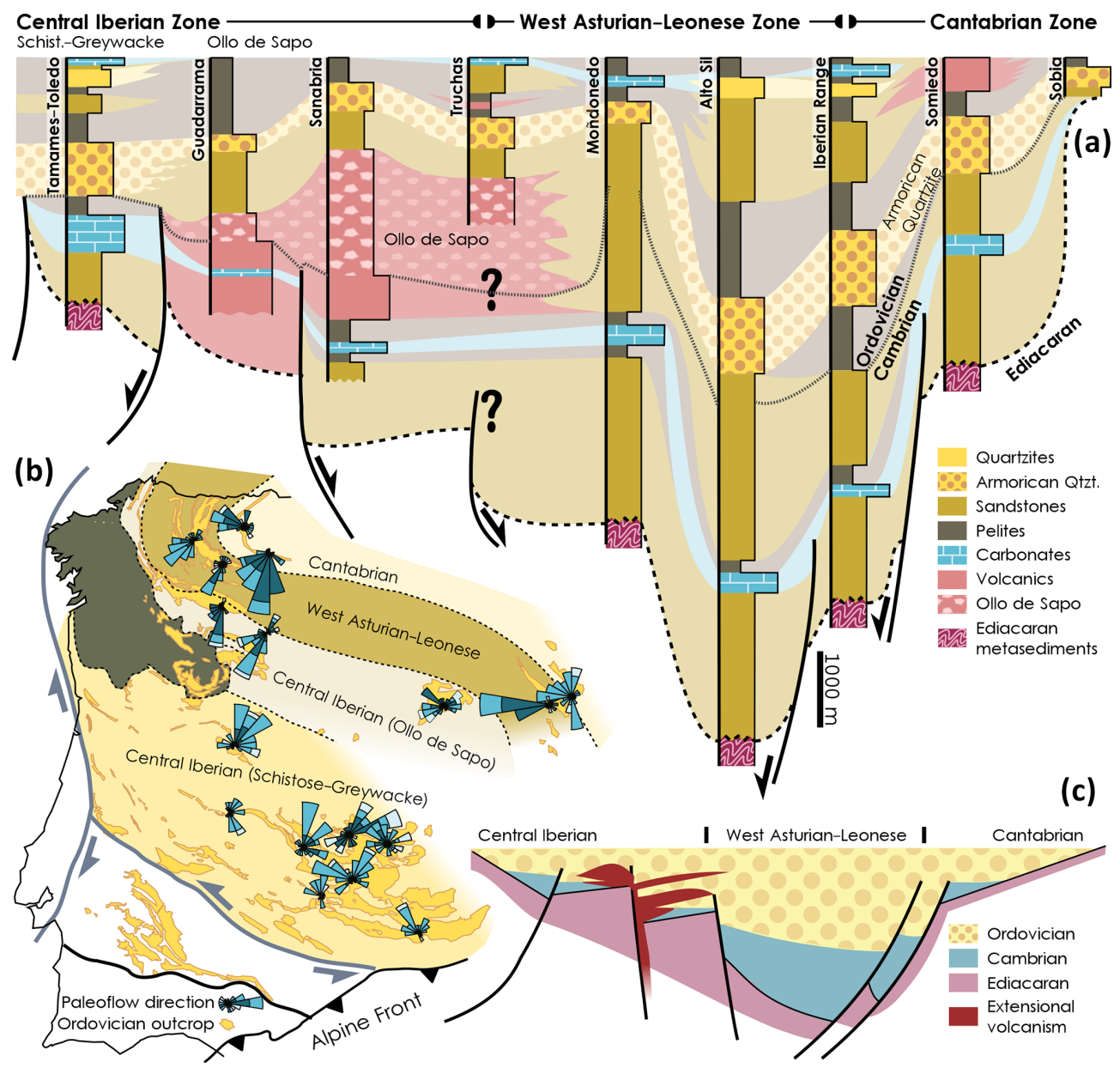

Figure 3. (a) Stratigraphic synthesis of the Gondwanan platform series in northwestern Iberia. Cantabrian Zone columns are based on Aramburu et al. (2002), Bastida (2004), Murphy et al. (2008), and Pastor-Galán et al. (2013a, b). Iberian Range is based on Gozalo et al. (2008), Mergl and Zamora (2012), and Calvín-Ballester and Casas (2014). West Asturian-Leonese Zone stratigraphy is based on PérezEstaún et al. (1990), Marcos et al. (2004), Martínez Catalán et al. (2004a), and Gutiérrez-Marco et al. (2019). Central Iberian Zone is based on Díez Balda (1986), Valladares et al. (2000), Montes (2007), Martínez Catalán et al. (2004b), del Moral and Sarmiento (2008), and GarcíaArias et al. (2018). (b) Ordovician paleocurrent orientations are modified from Shaw et al. (2012). (c) Schematic basin architecture inferred from the stratigraphic compilation.

phism (e.g., López-Carmona et al., 2014; Martínez Catalán et al., 2019). The oceanic rocks of this zone are classically interpreted as a Rheic Ocean suture (e.g., Martínez Catalán et al., 2009). Recent interpretations support its origin as a minor oceanic basin or seaway within the realm of Gondwana (e.g., Pin et al., 2002; Arenas et al., 2016).

The South Portuguese Zone constitutes the Laurussian foreland fold-and-thrust belt in the Iberian Variscides (e.g., Pereira et al., 2012; Pérez-Cáceres et al., 2017). It contains three units: (1) the Pulo de Lobo, a low grade metamorphic accretionary prism with clastic sedimentary rocks and basalts with a mid-ocean ridge basalt (MORB) signature (e.g., Azor et al., 2019; Pérez-Cáceres et al., 2020) sometimes considered an independent zone; (2) the Iberian Pyrite Belt, which is a world-class volcanogenic massive sulfide deposit formed between 390 and $330 \mathrm{Ma}$ (e.g., Oliveira et al., 2019a, b); and
(3) the Baixo Alentejo Flysch, which is located to the southwest and is a synorogenic composite turbiditic sequence with ages from $\sim 330$ to $\sim 310 \mathrm{Ma}$ (Oliveira et al., 2019b). The boundary between the South Portuguese and Ossa-Morena zones is a sinistral shear zone (the so-called Southern Iberian shear zone in the Beja-Acebuches oceanic-like unit; CrespoBlanc and Orozco, 1988; Quesada and Dallmeyer, 1994; Pérez-Cáceres et al., 2016) that contains a strongly deformed amphibolitic belt with oceanic affinity (Munha et al., 1986; Munha, 1990; Quesada et al., 2019). This belt potentially represents dismembered relics of the Rheic Ocean and/or a subsidiary seaway that opened during a Variscan transtensional event in southwestern Iberia (e.g., Pérez-Cáceres et al., 2015; Quesada et al., 2019).

Finally, Paleozoic rocks occur sporadically within the Betic-Alpine chain. Their lithological monotony, paucity of 
fossils, and the intensity of deformation and metamorphism during Alpine orogeny make recognizing the original features of the different successions challenging (e.g., MartínAlgarra et al., 2019). Some faunal and detrital zircon studies suggest that the Paleozoic outcrops in the Betics may be similar to the most continental-ward realms of the Gondwanan platform (i.e., the Cantabrian Zone; e.g., RodríguezCañero et al., 2018; Jabaloy-Sánchez et al., 2018). Following the latest plate reconstructions of the Mediterranean during Mesozoic-Cenozoic times, the Paleozoic units of the BeticRif chain may have been located proximal to the present-day position of the Balearic Islands (van Hinsbergen et al., 2020).

The Variscan orogen in Iberia shows multiple deformation, metamorphic, and magmatic events (e.g., Martínez Catalán et al., 2014; Azor et al., 2019; Fig. 2) that evolved diachronously from the suture towards the external zones (Dallmeyer et al., 1997). (1) An initial continent-continent collision began ca. 370-365 Ma, which produced highpressure metamorphism (e.g., Lopez-Carmona et al., 2014). (2) Between 360 and $330 \mathrm{Ma}$ a protracted shortening phase occurred, frequently divided into main phases $\mathrm{C} 1$ and $\mathrm{C} 2$, that was accompanied by Barrovian-type metamorphism (e.g., Dias da Silva et al., 2020) and plutonism at $\sim 340 \mathrm{Ma}$ (e.g., Gutiérrez-Alonso et al., 2018). (3) An extensional collapse event, so-called E1, occurred at $\sim 333-317 \mathrm{Ma}$, which formed core complexes and granitic domes in the Central Iberian and West Asturian-Leonese zones (Fig. 2c; e.g., Alcock et al., 2009; Díez-Fernández and Pereira, 2016; LópezMoro et al., 2018). This event is coeval and genetically linked to the formation of the foreland fold-and-thrust belt of the Cantabrian Zone (e.g., Gutiérrez-Alonso, 1996). (4) A late Carboniferous shortening event (C3) occurred ca. 315$290 \mathrm{Ma}$ and is interpreted as having resulted in the formation of the Cantabrian Orocline and being accompanied by the intrusion of mantle-derived granitoids (Fig. 2c; e.g., GutiérrezAlonso et al., 2011a, b; Pastor-Galán et al., 2012a). (5) A final early Permian extensional event (E2), mostly found in the Central Iberian Zone, resulted in the formation of core complexes and regional doming (Dias da Silva et al., 2020). (6) A final shortening event (C4), possibly coeval with E2, resulted in widespread brittle deformation (e.g., Azor et al., 2019; Fernández-Lozano et al., 2019).

In southwestern Iberia, the aforementioned Variscan deformation events are characterized by a dominant sinistral component, which contrasts with the general dextral component recognized in most other regions of the orogen (e.g., Martínez Catalán, 2011; Gutiérrez-Alonso et al., 2015). Early collisional structures (C1) formed NE vergent recumbent folds in the southernmost Central Iberian Zone and SW vergent folds and thrusts in the Ossa-Morena and South Portuguese zones. This phase continued with a transtensional event that heterogeneously extended the continental lithosphere (e.g., Pérez-Cáceres et al., 2015). Coevally, an important extension-related magmatic event happened, perhaps assisted by a plume-type mantle (Simancas et al., 2006) or because of slab break-off (Pin et al., 2008). After this transtensional event, significant sinistral transpression occurred forming the extensive shear zones to the north and south of the Ossa-Morena Zone (Fig. 2b), which accommodated the majority of transcurrent motion. However, sinistral displacements are observed all along the Ossa-Morena and South Portuguese zones. Pérez-Cáceres et al. (2016) estimated over $1000 \mathrm{~km}$ of collisional convergences in southwestern Iberia, most of which correspond with sinistral displacements parallel to terrane boundaries.

\section{Synthesis on the geometry and kinematics of the Cantabrian Orocline}

Understanding the geometry, kinematic evolution, and mechanics of curved mountain systems is crucial to developing paleogeographic and tectonic reconstructions and understanding of past geodynamics (e.g., Marshak, 2004; Van der Voo, 2004; Li et al., 2012; van Hinsbergen et al., 2020). Introduced by Carey (1955, p. 257), an orocline (from Greek $o \rho o \zeta$, mountain, and $\kappa \lambda \iota v o$, bend) is " ... an orogenic system, which has been flexed in plan to a horse-shoe or elbow shape". Although sometimes used in the literature as a geometric description of any orogenic curvature, herein orocline is strictly used as the term for map-scale bends that underwent vertical-axis rotations (Weil and Sussman, 2004; Johnston et al., 2013; Pastor-Galán et al., 2017a). The kinematic classification of curved mountain belts (Weil and Susman, 2004; Johnston et al., 2013) distinguishes two end members: (1) primary orogenic curves, which describe those systems in which curvature is a primary feature of the orogen and is formed without significant or systematic vertical-axis rotations, and (2) secondary oroclines, where orogenic curvature was acquired due to vertical-axis rotations subsequent to primary orogenic building. Those systems whose curvature is the product of vertical-axis rotation during the primary orogenic pulse and/or for which only a portion of the observed curvature is secondary are termed progressive oroclines.

The orocline test (or strike test) evaluates the relationship between changes in regional structural trend (relative to a reference trend for an orogen) and the orientations of a given geologic fabric element or magnetization (relative to a reference direction). In terms of evaluating developmental kinematics, the most relevant geologic marker is paleomagnetic declination, which can be used to quantitatively evaluate total and systematic rotations as a function of along-strike variability. Once acquired, data are plotted on Cartesian coordinate axes with the strike $(S)$ of the orogen (relative to a reference) along the horizontal axis and the fabric azimuth ( $F$ relative to a reference) along the vertical axis. The test originally used a basic least squares (OLS) regression (Schwartz and Van der Voo, 1983) to estimate the slope (coded $m$ in formulas), ideally between 0 and 1 , which then is interpreted with respect to vertical-axis kinematics. More recently, Yon- 
kee and Weil (2010) and Pastor-Galán et al. (2017a) introduced more robust statistics to estimate the correlation slope and its uncertainty, considering and propagating errors of the input data. Primary orogenic bends show no change in paleomagnetic declination orientations with varying structural trends; therefore, the slope is expected to be 0 . In progressive oroclines, the declination variation records some fraction of the total observed orogenic strike variability, and thus the slope would range between 0 and 1 , depending on the amount of primary curvature. Secondary oroclines are those in which the paleomagnetic vectors record $100 \%$ of the rotation, yielding slopes of 1 , which means that the orogenic system must have started as a roughly linear system that then underwent secondary vertical-axis rotations until its presentday curvature was acquired. The slope obtained with the orocline test can only be confidently interpreted when the chronology of fabric formation is well known.

The trend of the Variscan belt in Iberia follows a sinuous " $\mathrm{S}$ " shape that is especially prominent in the northwest region of the Iberian Peninsula and then becomes more subtle due to the predominance of younger cover sequences in the central and eastern regions of the peninsula (Figs. 1 and 2). This dramatic geometry has stimulated a century-long scientific debate as to its origin (e.g., Suess, 1892; Staub, 1926; Martínez Catalán et al., 2015). To the north and convex to the west is the Cantabrian Orocline, and to the center-south and convex to the east is the Central Iberian curve. The overall trend of the Cantabrian Orocline starts in Brittany (France) and southern England and then curves through the Bay of Biscay and then south into central northern Iberia (Figs. 1, 2 and 4). The Cantabrian Orocline (also known as IberoArmorican Orocline or Arc, Asturian Arc, or CantabrianAsturias Arc) is arguably the first curved orogen that was scientifically described, recognized by the change in the structural trend of mapped thrusts and fold axes (Schultz, 1858; Barrois, 1882; Suess, 1892). The Cantabrian Orocline traces an arc with a curvature close to $180^{\circ}$ within the central Cantabrian Zone (the Gondwanan foreland in Iberia; Fig. 2) and opens to approximately $150^{\circ}$ as one moves to the outer arc reaches (Fig. 1). At the crustal-scale, the Cantabrian Orocline represents a first-order vertical-axis buckle fold in plan view that refolds preexisting Variscan structures (e.g., Julivert and Marcos, 1973; Weil et al., 2001). The inner arc of the orocline, or the Cantabrian Zone, is characterized by tectonic transport towards the core of the orocline; i.e., the orocline has a contractional core, where low finite strain values and locally developed cleavages occur (Pérez-Estaún et al., 1988; Gutiérrez-Alonso, 1996; Pastor-Galán et al., 2009). Within the inner core, a variety of structures record non-coaxial strain, which produced complex interference folds and rotated thrust sheets (e.g., Julivert and Marcos, 1973; Julivert and Arboleya, 1984; Pérez-Estaún et al., 1988; Aller and Gallastegui, 1995; Weil, 2006; Weil et al., 2013; Pastor-Galán et al., 2012b; Shaw et al., 2015, 2016; Del Greco et al., 2016). In contrast, the outer arc shows a vertical-axis fold with a ca. $150^{\circ}$ interlimb angle which was accommodated by significant shearing, both dextral and, in lesser amounts, sinistral, that was penecontemporaneous with vertical-axis rotation (Gutiérrez-Alonso et al., 2015). Weil et al. (2013, 2019) extensively review the geometry of the Cantabrian Orocline.

All kinematic data studied so far support a model in which the Cantabrian Orocline formed due to secondary verticalaxis rotation in a period of time later than $315 \mathrm{Ma}$ and earlier than $290 \mathrm{Ma}$. Overall, the southern limb of the orocline rotated counterclockwise (CCW) and the northern limb clockwise (CW; Fig. 4). Orocline formation happened subsequent to the main shortening phases of the orogen $(\mathrm{C} 1$ and $\mathrm{C} 2)$ and late-stage orogenic collapse (E1), and, therefore, it is an ideal example of a secondary orocline in the strictest sense. The development of the Cantabrian Orocline requires the existence of a roughly linear orogenic belt during the early Variscan closure of the Rheic Ocean (with a roughly N-S orientation in present-day coordinates), which was subsequently bent in plan view into an orocline during the late stages of Pangea's amalgamation. Such an interpretation is grounded in extensive paleomagnetic studies (e.g., Hirt et al., 1992; Parés et al., 1994; Stewart, 1995; van der Voo et al., 1997; Weil, 2006; Weil et al., 2000, 2001, 2010b), as well as through important contributions from structural (e.g., Gutiérrez-Alonso, 1992; Kollmeier et al., 2000; MerinoTomé et al., 2009; Pastor-Galán et al., 2011, 2014; Shaw et al., 2015) and geochronological studies (e.g., Tohver et al., 2008; Gutiérrez-Alonso et al., 2015). Weil et al. (2013) provided a comprehensive review of the kinematic constraints, which were updated by Pastor-Galán et al. (2017a) and by Weil et al. (2019).

\section{The intriguing geometry of the Central Iberian curve}

The more southern Central Iberian curve has a similar magnitude but opposite curvature compared to the Cantabrian Orocline (Figs. 1 and 2b). This structure has been referred to as the Central Iberian curve, arc, bend, or orocline. In this paper, we use "Central Iberian curve". The other aforementioned terms involve still unknown parameters or are misleading: e.g., orocline implies kinematics (Weil and Sussman, 2004), bend refers to a mechanism of formation (e.g., Fossen, 2016), and arc could be ambiguous since the term is commonly used for volcanic chains. The Central Iberian curve was first described by Staub (1926) and was termed the Castilian bend. Continental drift pioneers paid some attention to Staub's description (e.g., Holmes, 1929; Du Toit, 1937), but the curved structure remained largely ignored for multiple decades (e.g., Martínez Catalán et al., 2015). The hypothesis of a largescale curvature in Central Iberia made a comeback at the beginning of the 21 st century with a study of Variscan porphyroblast kinematics across Iberia by Aerden (2004). Since then, several attempts to unveil its geometry and kinematics have given contrasting results. 

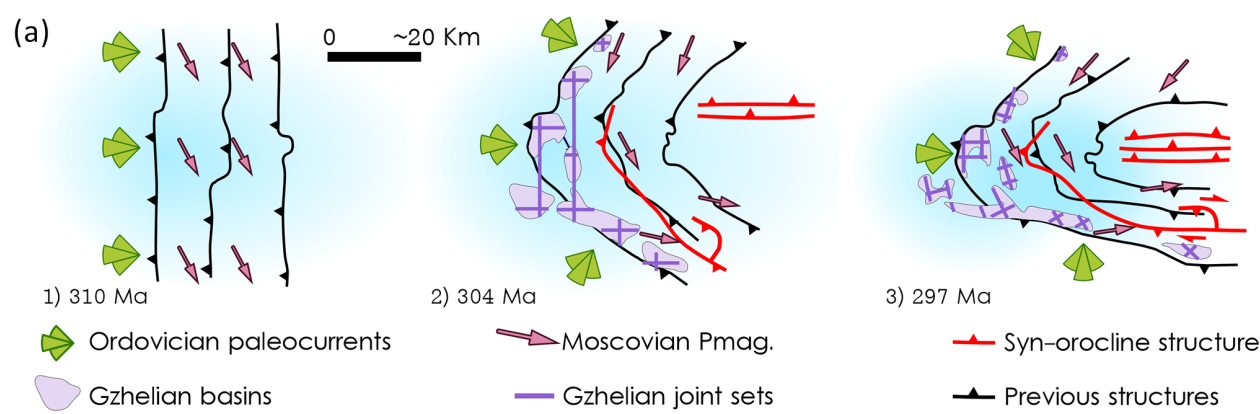

3) $297 \mathrm{Ma}$
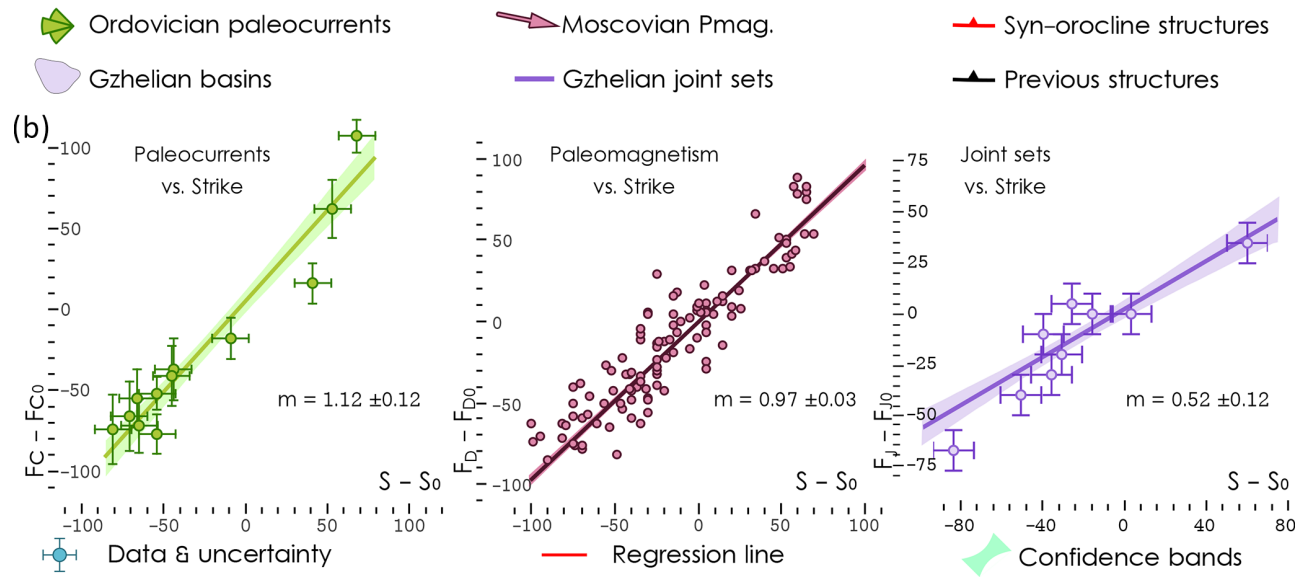

Figure 4. (a) The kinematic evolution of the Cantabrian Orocline in its core, the Cantabrian Zone, inferred from total least squares (TLS) orocline tests (Pastor-Galán et al., 2017a). (b) Three orocline (strike) tests used to constrain the kinematics of the Cantabrian Orocline. The Ordovician paleocurrents, which predate any orogenic movement, recorded the complete vertical-axis rotation history and yield a slope $(m)$ of $\sim 1$. The Moscovian paleomagnetic data (from Weil et al., 2013; Pmag.), which postdate the main orogenic phases (C1, C2, and E1) and are coeval with C3, show a slope of $\sim 1$. The orocline test of the Gzhelian joint sets (from Pastor-Galán et al., 2011) shows a slope of $\sim 0.5$, which indicates that part of the orocline was already formed between 304 and $300 \mathrm{Ma}$.

The elusive nature of the Central Iberian curve resides in the poor exposure of its putative hinge (Fig. 2). The hinge of the Cantabrian Orocline crops out extensively, and the changes in fold-and-thrust axis trends are observable at high resolution from aerial photographs and are readily mapped using outcrop-scale observations. In contrast, the alleged hinge of the Central Iberian curve is largely covered by Mesozoic and Cenozoic basins (Fig. 2). The curvature is most recognizable at the boundary between the Galicia-Trasos-Montes and Central Iberian zones (Fig. 2a; Aerden, 2004; Martínez Catalán, 2012). The thrust fault that bounds those areas traces close to a $180^{\circ}$ curvature and marks the emplacement of the most distal units. Before the revival of Staub's curved geometry along the entire Central Iberian Zone, there were several attempts to explain the curved shape of the Galicia-Tras-os-Montes Zone. Some consider the GaliciaTras-os-Montes Zone a block that escaped during an early Variscan (C1) non-cylindrical collision, forming a extrusion wedge towards areas that underwent a lesser amount of shortening (Martínez Catalán, 1990; Dias da Silva et al., 2015, 2020), or, alternatively, a klippe of a larger allochthonous thrust sheet or the product of an interference pattern between C2, E1, and C3 structures (e.g., Ries and Shackleton, 1971; Martínez Catalán et al., 2002; Rubio Pascual et al., 2013; Díez-Fernández and Arenas, 2015).
In addition to the Galicia-Tras-os-Montes Zone, the other areas that show a certain degree of curvature are to the $E$ and SE of the Central Iberian Zone. There, an approximately $20^{\circ}$ change in strike of the Iberian ranges (northeastern Iberia; Fig. 2a) is observed, which represents the only known outcrop of the hinge of the Central Iberian curve's outer arc. The rest of the curvature has been implied with indirect observations leading to three competing geometric proposals for the Central Iberian curve (Fig. 2b). The main arguments used to constrain the geometry of the Central Iberian curve are (1) the geometry of Galicia-Tras-os-Montes folds and the orientation of observed garnet inclusion trails (Aerden, 2004; Fig. 2b-1); (2) the alignment of aeromagnetic anomalies and fold trends in the Iberian ranges and the E-SE Central Iberian Zone (Martínez Catalán, 2012; Fig. 2a and b-2); and (3) the regional distribution of paleocurrents recorded in Ordovician quartzites (Shaw et al., 2012; Figs. 2b-3 and 3). All proposed geometries share two features: (1) the curvature runs parallel to the Central Iberian Zone and is located in the center-west of Iberia and (2) all place the Galicia-Tras-os-Montes Zone in the core of the curve with the curved axial traces crosscutting the Morais Complex, which is a set of mafic and ultramafic rocks that is roughly circular in shape (Fig. 2b; Dias da Silva et al., 2020). 

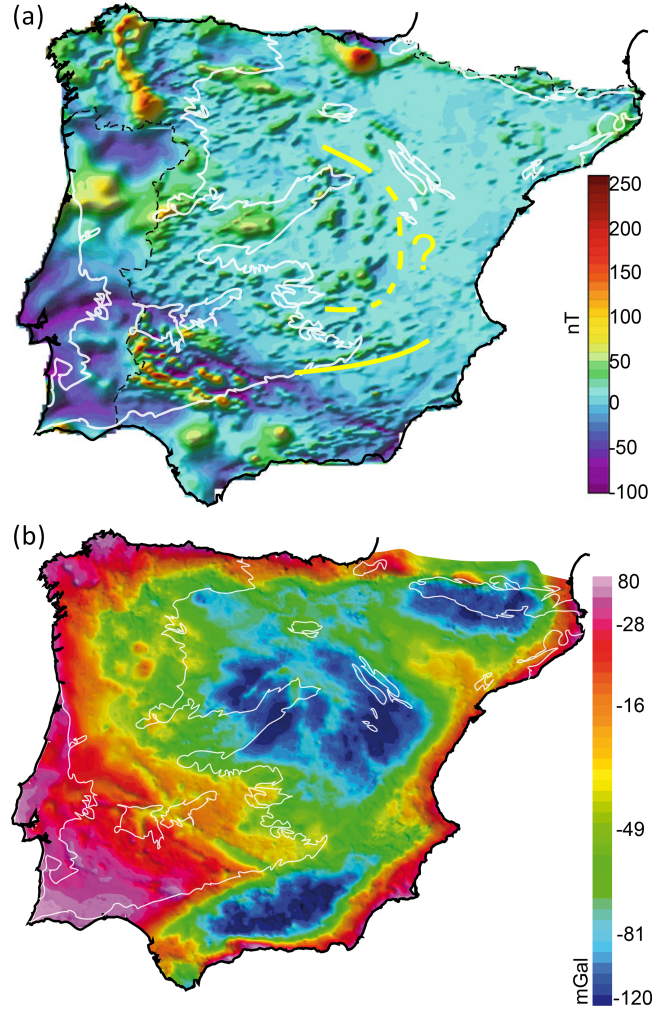

Figure 5. (a) Aeromagnetic map of Spain (Ardizone et al., 1989, for Spain and the World Digital Magnetic Anomaly Map, WDMAM, project) and Portugal (modified from Martínez Catalán, 2012, and Martínez Catalán et al., 2015) showing the possible trace of the Central Iberian curve. (b) Bouguer anomalies of the Iberian Peninsula, modified from Ayala et al. (2016). Gravity anomalies do not reflect the geometry of the Cantabrian Orocline or the Central Iberian curve but are related to the Cenozoic Alpine lithospheric structure.

Aerden (2004) compared the orientation of inclusions in metamorphic porphyroblasts across the Variscan allochthonous terranes of the NW Iberian Massif and found that inclusion trails maintain a constant north-south orientation. Comparing such results with the trend of the Variscan fold axes in the Central Iberian Zone (Fig. 2a) and a novel interpretation of the aeromagnetic anomalies of the Iberian Peninsula (Fig. 5a), Aerden suggested a geometry in which the Central Iberian curve was more prominent in the outer arc than in the inner arc (Fig. 2b-1). In Aerden's view, the geometry of the Galicia-Tras-os-Montes Zone does not represent a large-scale curvature but rather the original shape of the nappe, perhaps re-tightened during $\mathrm{C} 3$ deformation. In contrast, the Iberian ranges and the SE Central Iberian Zone represent the more curved sector (Fig. 2b-1). In the model of Aerden (2004), the Ossa-Morena and South Portuguese zones are not part of the Central Iberian curvature.

Martínez Catalán (2012) reinterpreted Aerden's analysis of aeromagnetic map data (Fig. 5a) and the interpreted structural trends of $\mathrm{C} 1-\mathrm{C} 2$ fold axes from Central Iberian Zone structures (Fig. 2a). In Martínez Catalán's model, the Central Iberian curvature is a symmetrically arcuate shape in which the orogen trend changes equally in the inner and outer arc and is comparable in size to the Cantabrian Orocline but with opposite curvature and less shortening. This geometric model also excludes the Ossa-Morena and the South Portuguese zones as elements involved in the formation of the curvature (Fig. 2b-2).

Finally, Shaw et al. (2012) studied the orientation of paleocurrents in Ordovician Armorican Quartzite (e.g., Aramburu, 2002), which is one of the most prominent rocks exposed in Iberia (Fig. 3). These authors found that paleocurrents fanned outward with respect to the Cantabrian Orocline curve and are approximately perpendicular to the structural trend throughout the peninsula (Fig. 3). Shaw et al. (2012) assumed that the direction and sense of paleocurrents were originally parallel throughout all zones, and they concluded that the Central Iberian curve is part of a " $\mathrm{S}$ " shape isoclinal structure with a similar magnitude of curvature to the Cantabrian Orocline (Fig. 2b-3). It is unclear from the Shaw et al. (2012) model what the involvement of the Ossa-Morena and South Portuguese zones in the overall curve is (if any) nor what the prospective location is of the external zones of the orogen (Cantabrian Zone) with respect to the overall curvature.

\section{Move over once, move over twice: kinematic constraints}

Late Variscan kinematic data (315-290 Ma; C3, E2, and C4 phases) in the Central Iberian curve were scarce prior to the revival of Staub's Central Iberian curve (e.g., Vergés, 1983; Julivert et al., 1983; Parés and van der Voo, 1992). More recently, a wealth of studies have been published on the kinematics of forming the Central Iberian curve (Fig. 2b), which are reviewed below.

\subsection{Structural geology and geochronology}

Curved orogens that result from differential vertical-axis rotations develop remarkable structures within their hinges, in which compressive and extensive radial structures often develop in combination with tangential shear structures (e.g., Li et al., 2012; Eichelberger and McQuarrie, 2015). With the re-emergence of the Central Iberian curve debate, several studies have re-evaluated the well-documented structures of the Central Iberian Zone to constrain the origin and kinematics of curvature. The majority of studies focused on the hinge zone of the curve in the area surrounding GaliciaTras-os-Montes (e.g., Dias da Silva et al., 2014; Jacques et al., 2018a), but some do explore areas in the outer-arc (e.g., Palero-Fernández et al., 2015; Gutiérrez-Alonso et al., 2015). The following section synthesizes the findings of new field, structural, and geochronological analyses from around 
the hinge of the Central Iberian curve and its surrounding regions. The reviewed studies identify several deformation events that are linked to regional Variscan deformation phases (Fig. 2a).

The first deformation event is an early generation of upright to overturned cylindrical folds with an associated axial planar cleavage $(\mathrm{C} 1)$. The $\mathrm{C} 1$ fold axes plunge variably from horizontal to nearly vertical (e.g., Jacques et al., 2018a, b). The original trend of the fold axes was parallel to the orogen (e.g., Pastor-Galán et al., 2019b); however, interference with younger deformation events has created complicated geometries (e.g., Díez Fernández et al., 2013; Palero-Fernández et al., 2015). The emplacement of the allochthonous units of the Galicia-Tras-os-Montes Zone (commonly referred as C2) is closely associated with development of $\mathrm{C} 1$ folds but is restricted to shear zones located along the boundary between the latter and the Central Iberian Zone (Dias da Silva et al., 2020). This phase includes the orogen-parallel emplacement of the allochthonous Galicia-Tras-os-Montes units and its associated thrusts (Fig. 2a). The non-coaxial nature of the emplacement of this allochthonous nappe produced folding interference and local vertical-axis rotations (Dias da Silva et al., 2020). Prograde Barrovian metamorphism (known as M1) reached its pressure peak at the end of C2 (Rubio Pascual et al., 2013).

After $\mathrm{C} 1$ and $\mathrm{C} 2$, the resulting thickened crust gravitationally collapsed (Macaya et al., 1991; Escuder Viruete et al., 1994; Díez-Balda et al., 1995; Díez-Montes et al., 2010). This gravitational collapse (phase E1) formed gneiss-dome core complexes between 330 and 317 Ma (e.g., Díez Fernández and Pereira, 2016) especially in the core of the Central Iberian curve (Fig. 2c; e.g., Martínez Catalán, 2012). This phase formed large subhorizontal extensional detachments that exhumed to depths of the middle crust (e.g., RubioPascual et al., 2013; Dias da Silva et al., 2020). General decompression produced a Buchan-type metamorphic event (M2; e.g., Rubio-Pascual et al., 2016; Solís-Alulima et al., 2019) and widespread anatectic melting (e.g., López-Moro et al., 2018; Pereira et al., 2018). The E1 phase developed a fold system with subhorizontal axes and a penetrative subhorizontal cleavage (e.g., Dias da Silva et al., 2020). Mapped folding geometries indicate the deflection of $\mathrm{C} 1$ folds into overturned positions within the E1 deformation zones (e.g., Díez Fernández et al., 2013; Díez Fernández and Pereira, 2016; Pastor-Galán et al., 2019b). In addition to large-scale extensional deformation and Buchan metamorphism, E1 developed a regional dome-and-basin pattern, resulting in portions of the allochthonous terranes tectonically transported into basins (e.g., Días da Silva et al., 2020).

The structures developed during $\mathrm{C} 1-\mathrm{C} 2$ compression and $\mathrm{E} 1$ extension are refolded by a younger shortening phase (C3; syn-Cantabrian Orocline). C3 formed upright open folds and conjugate subvertical shear zones (e.g., GutiérrezAlonso et al., 2015; Díez Fernández and Pereira, 2017; Dias da Silva et al., 2020). C3 was coeval with regional retro- grade metamorphism (M3) and with the intrusion of mantlederived granitoids (Fig. 2c; e.g., Gutiérrez-Alonso et al., 2011a) surrounded by contact metamorphic aureoles (e.g., Yenes et al., 1999). The age of the $C 3$ event ranges from 315 and $290 \mathrm{Ma}$ (e.g., Jacques et al., 2018a) and is concomitant with the formation of the Cantabrian Orocline (e.g., PastorGalán et al., 2015a). Ductile deformation, including folding with axial planar cleavage (e.g., Dias da Silva et al., 2020; Pastor-Galán et al., 2019b) and the development of conjugate shear zones, occurred at the early stages of C3 (315-305 Ma; Gutiérrez-Alonso et al., 2015; Díez-Fernández and Pereira, 2017; Jacques et al., 2018b) and was followed by brittle deformation that formed cross-joint sets and vein swarms with Sn-W mineralization (Jacques et al., 2018a, b). The conjugated shear zones, some of them with hundreds of kilometers of displacement, were active during the period 315$305 \mathrm{Ma}$ based on direct $\mathrm{Ar}-\mathrm{Ar}$ dating of the shear zones (Gutiérrez-Alonso et al., 2015) and cross-cutting relationships with precisely dated igneous rocks (Díez-Fernández and Pereira, 2017). Note that these shear zones show a younger age with respect to the sinistral shear zones that bound the Ossa-Morena and South Portuguese zones (340330 Ma; e.g., Dallmeyer et al., 1993). New studies in the Central Iberian Zone have determined that several folds, previously interpreted as C1 (e.g., the Tamames-Marofa-Sátão synform), are in fact $\mathrm{C} 3$ structures, possibly nucleated within existing C1-C2 structures (e.g., Dias da Silva et al., 2017; Jacques et al., 2018b). The remarkable continuity along the Central Iberian Zone of these folds (Fig. 2a), previously interpreted as C1 (e.g., Díez-Balda et al., 1990; Ábalos et al., 2002; Dias and Ribeiro, 1994; Dias et al., 2016), suggests the ubiquity and importance of this deformation phase.

The N-S shortening (in present-day coordinates) of $\mathrm{C} 3 \mathrm{de}-$ formation continued through the early Permian under brittle conditions (so-called C4 event) (e.g., Dias da Silva et al., 2020) and overlapped with the formation of $E 2$ extensional faults (Fig. 2a; Dias and Ribeiro, 1991; Dias et al., 2003; Rubio Pascual et al., 2013; Arango et al., 2013; FernándezLozano et al., 2019; Dias da Silva et al., 2020). C4 N-S compression produced a series of NNE-SSW and NNWSSE brittle faults (Gil Toja et al., 1985; Dias and Ribeiro, 1991; Dias et al., 2003; Fernández-Lozano et al., 2019) and associated subvertical and subhorizontal widespread kinkbands (e.g., Aller et al., 2020; Dias da Silva et al., 2020) that are today exposed in northern Iberia. E2 developed core complex-like structures with extensional shear zones that further telescoped M2 metamorphic isograds between the anatectic cores of gneiss domes and the associated hanging wall units. This event favored subhorizontal folding and crenulation cleavage development in the footwall, together with kink-band generation in the upper low-grade structural levels. 


\subsection{Paleomagnetism}

Paleomagnetism investigates the Earth's ancient magnetic field as it is recorded in rocks. Among other features, rocks can record the orientation of the magnetic field at the time of magnetization (e.g., Tauxe, 2010). The magnetic vector can be geometrically defined by two components: inclination, which is a function of the paleolatitude (being $90^{\circ}$ at the poles and $0^{\circ}$ at the Equator) at the time of magnetization acquisition, and declination, which is a measure of the horizontal angular difference between the recorded magnetic direction and true north, thereby allowing for the quantification of any vertical-axis rotations if a reference paleomagnetic pole is known for the region of interest at the time of magnetization acquisition. Paleomagnetism is the best tool to quantify vertical-axis rotations in orogens due to the independence of the magnetic field from an orogen's deformation and evolution (e.g., Butler, 1998).

Despite its uniqueness to study paleolatitudes and verticalaxis rotations, paleomagnetism is not flawless. Paleomagnetic data can yield spurious rotations when the local and regional structures are not properly defined and their geometries and kinematic histories are not adequately corrected for (e.g., Pueyo et al., 2016). In addition, the age of magnetization acquisition is not necessarily equivalent to the age of the sampled rock. Remagnetizations are ubiquitous, especially in orogens (Weil and Van der Voo, 2002; Pueyo et al., 2007; Huang et al., 2017). In remagnetized rocks, the primary magnetization is replaced or overprinted due to a set of geologic processes acting alone or in concert - usually represented by a combination of thermal or chemical reactions (e.g., Jackson, 1990). Nevertheless, remagnetizations can be useful for interpreting deformation history if the relative timing of the overprint can be established and a well-constrained reference direction for that age is known (e.g., Weil et al., 2001; Izquierdo-Llavall et al., 2015; Calvín et al., 2017).

In addition to knowing the structural geology and the timing of magnetization of the studied rocks, understanding and quantifying local and regional vertical-axis rotations require a paleomagnetic reference pole for comparison. Permian and Mesozoic paleomagnetic studies in Iberia indicate that Iberia was a relatively stable plate from at least Guadalupian times (ca. 270 Ma) to the opening of the Bay of Biscay in the Cretaceous (e.g., Gong et al., 2008; Vissers et al., 2016). Weil et al. (2010b) calculated an early Permian pole for stable Iberia, which will be used herein as a reference for any vertical-axis rotation analysis (hereafter eP pole or eP component). The virtual geomagnetic pole (VGP) values of Weil et al. (2010b) are $P_{\text {lat }}=43.9, P_{\text {long }}=203.3$, and $\alpha_{95}=5.4$ and, when transformed into paleomagnetic components, have $\mathrm{a} \sim 0^{\circ}$ inclination (equatorial) and declinations that range from 150 to $160^{\circ}$ (from NW to SW, respectively) depending on where in Iberia you are referencing. In Fig. 6 (red arrows), a compilation of declinations that form part of this compos- ite pole and other eP components found in recent studies are presented.

For the Central Iberian curve, the voluminous paleomagnetic database from the Cantabrian Orocline can be used to partially constrain its kinematics (e.g., Weil et al., 2013). The orocline test for the Cantabrian Orocline (Fig. 4) quantifies the degree of differential vertical-axis rotation of variously striking Variscan tectonic belts in northern Iberia. If the Central Iberian curve is a product of vertical-axis rotation, paleomagnetic declinations would bend around the Central Iberian curve opposite to that of the Cantabrian Orocline. With a well-constrained orocline test, as in the Cantabrian Orocline (Fig. 4), one can use the paleomagnetic strike-test correlation slope to establish expected declinations for any along-strike portion of the orogen (Pastor-Galán et al., 2017b).

Before the resurgence of the Central Iberian curve, the only available pre-Permian paleomagnetic studies to the south and west of the Cantabrian Zone in the Iberian Massif were from the Beja Gabbroic Massif, Portugal (Perroud et al., 1985), and the Almadén syncline volcanics (Perroud et al., 1991; Parés and Van der Voo, 1992). The Beja-area study presented varied inclinations and declinations in the gabbros and complex overprints elsewhere. Perroud et al. (1985) did not consider any structural correction for the results as they assumed the gabbro was undeformed. Recently, Dias da Silva et al. (2018) showed that the area underwent intense deformation during the Carboniferous. Therefore, interpretation of this dataset is complicated without knowing the proper structural correction needed to restore the magnetization to its palinspastic orientation.

Several articles with new paleomagnetic studies around the Central Iberian curve have been published since 2015 (Fig. 6). In general, these studies have reported a pervasive late Carboniferous (320 to $300 \mathrm{Ma}$ ) (re-)magnetization in sedimentary and igneous rocks (e.g., Pastor-Galán et al., 2015a, 2017b; Fernández-Lozano et al., 2016), which is largely penecontemporaneous with the intrusion of E1 extensional granites (López-Moro et al., 2018) and C3 synorocline mantle-derived granitoids (Fig. 2c; e.g., GutiérrezAlonso et al., 2011a). The following section describes the reported magnetizations from oldest to youngest.

Pastor-Galán et al. (2016) sampled for paleomagnetic analyses both E1 extensional granites (Fig. 2c; 320 Ma; e.g., López-Moro et al., 2018) from the Tormes and Martinamor domes and C3 mantle-derived granitoids from the Central System (Fig. 2c; 305-295 Ma; e.g., Gutiérrez-Alonso et al., 2011a). Both sets of plutons are located around the Galicia-Tras-os-Montes hinge of the Central Iberian curve (Figs. 2 and 6). The authors found an original component in E1 granites supported by a positive reversal test in both domes (Fig. 7). The magnetization has an inclination $($ Inc. $)=15^{\circ}\left(\right.$ paleolatitude $\left.(\lambda)=-7.6^{\circ}\right)$ and declination $($ Dec. $)=81^{\circ}$ (Fig. 7), which imply a northward movement of $700 \mathrm{~km}$ and $\mathrm{a} \sim 70^{\circ} \mathrm{CCW}$ rotation with respect to the $\mathrm{C} 3$ granites that showed an eP component (Dec. $\sim 150^{\circ}$, Inc. 


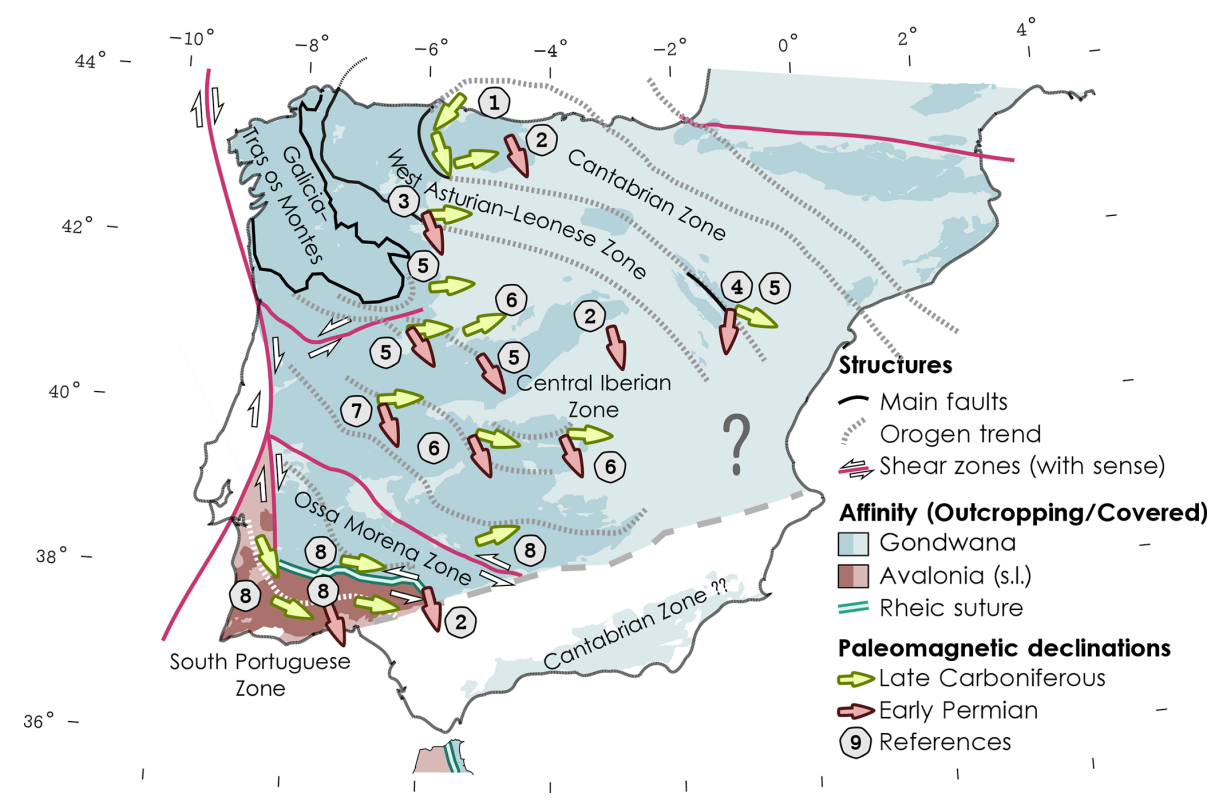

Figure 6. Paleomagnetic studies related to the Cantabrian Orocline and the Central Iberian curve: (1) synthesis of paleomagnetism in the core of the Cantabrian Orocline (see Weil et al., 2013); (2) Permian (eP) components synthesized in Weil et al. (2010b); (3) Ordovician volcanics and limestones (Laquiana) in the boundary between the West Asturian-Leonese and Central Iberian zones (Fernández-Lozano et al., 2016); (4) Devonian sedimentary sequences and Permian subvolcanics in the Iberian ranges (Pastor-Galán et al., 2018); (5) Permian dikes and sills (Calvín et al, 2014); (5) Anatectic granites (E1) and mantle-derived granitoids (C3) from Tormes dome and Central System (PastorGalán et al., 2016); (6) Cambrian limestones from Tamames (N) and los Navalucillos (S) (Pastor-Galán et al., 2015a); (7) Ediacaran-early Cambrian sedimentary rocks in the southern sector of the Central Iberian Zone (Pastor-Galán et al., 2017b); (8) Almadén volcanics from the Central Iberian Zone (Perroud et al., 1991; Parés and van der Voo, 1992; Leite Mendes et al., 2020) and Volcanic rocks from the southern Ossa-Morena and the South Portuguese zones (Leite Mendes et al., 2020).

$\sim 0^{\circ}$ ). Considering the positive reversal test in E1 granites and the significant difference in inclinations with respect to $\mathrm{C} 3$ granitoids (eP component), a magnetization age older than $318 \mathrm{Ma}$ was proposed (pre-Kiaman Superchron, 317$267 \mathrm{Ma}$; e.g., Langereis et al., 2010), which was interpreted as a primary magnetization. The $70^{\circ} \mathrm{CCW}$ Pennsylvanian rotation recorded in rocks from the Central Iberian curve hinge zone is in agreement with the expected rotation of the southern limb of the Cantabrian Orocline (Fig. 4; Weil et al., 2013).

At the putative outer arc of the Central Iberian curve in the Iberian ranges (Fig. 2), paleomagnetic and structural studies of Devonian and Permian rocks (Pastor-Galán et al., 2018) revealed that the eP component from Permian rocks had rotated $\sim 22^{\circ} \mathrm{CW}$ during the Cenozoic (Fig. 8; cf. PastorGalán et al., 2018). The Permian and Mesozoic rocks from the Iberian ranges show a consistent $\sim 22^{\circ} \mathrm{CW}$ rotation with respect to the apparent polar wander path (APWP) for Iberia (e.g., Pastor-Galán et al., 2018). This rotation likely happened during the Alpine orogeny, in which the northern area of the Iberian Range underwent more shortening than the southern part, resulting in a regional $\mathrm{CW}$ vertical-axis rotation (Izquierdo-Llavall et al., 2019). After restoring the Cenozoic rotation, the Devonian rocks show a positive reversal and fold test with inclinations that are steeper than ex- pected from the eP component $\left(\right.$ Dec. $=85.3^{\circ}$, Inc. $=12.7^{\circ}$, $\lambda=-6.4)$. This component is statistically indistinguishable from that of the E1 granites and the southern branch of the Cantabrian Zone, showing the same $70^{\circ} \mathrm{CCW}$ rotation from the time they were remagnetized (estimated $\sim 318 \mathrm{Ma}$ ) to the timing of the eP component (Fig. 8; Pastor-Galán et al., 2018). Once Cenozoic rotation is corrected for, the structural and paleomagnetic trends of the Iberian ranges become parallel to those in the southern limb of the Cantabrian Orocline, ruling out a Variscan or older origin for the outer Central Iberian curve (Fig. 8).

The remaining paleomagnetic works published on Central and southwestern Iberian rocks all reveal a ubiquitous late Carboniferous to early Permian remagnetization during the Kiaman superchron (Fernández-Lozano et al., 2016; PastorGalán et al., 2015a, 2016, 2017b; Leite Mendes et al., 2020). The authors of these papers calculated the expected declination for each site as if they were part of the Cantabrian Orocline (Fig. 9a). All localities where magnetizations predate the formation of the Cantabrian Orocline show the same expected rotations as the southern limb of the Cantabrian Orocline regardless of their position within the Central Iberian curve (to the hinge - Tormes and Martinamor domes and Iberian ranges; to the southern limb - Almadén syncline and South Portuguese Zone). Other locations, especially lime- 

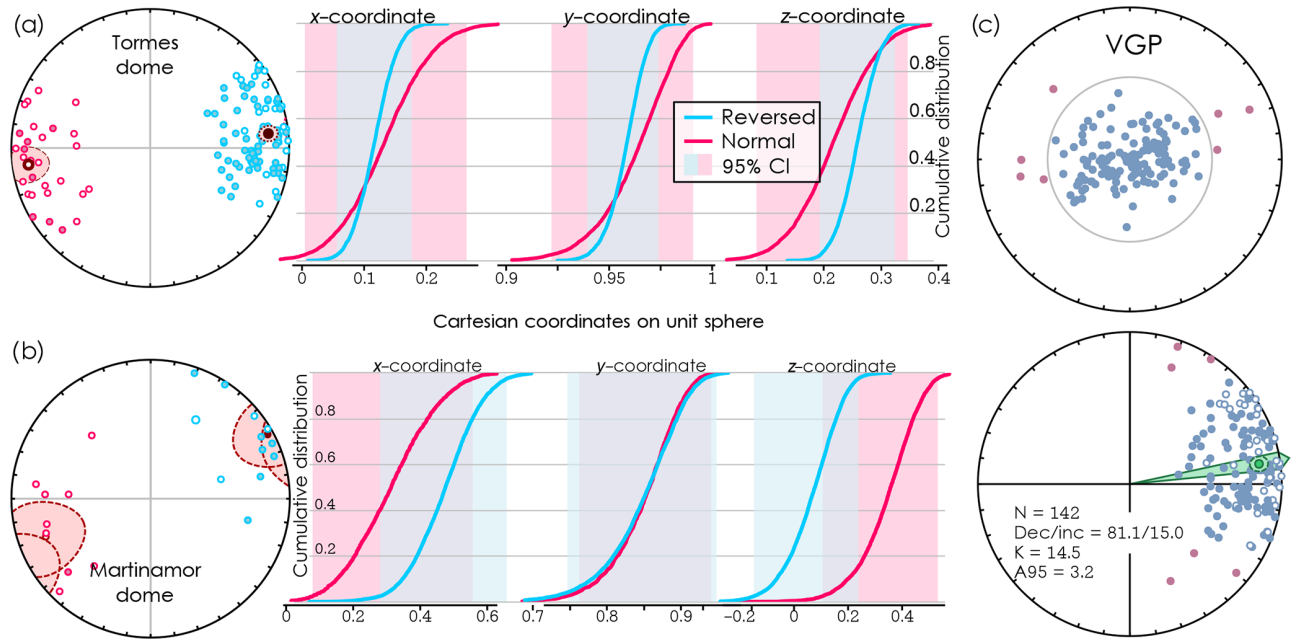

Figure 7. Magnetization components with a positive reversal test in the extensional anatectic granites of the Tormes (a) and Martinamor domes (b). This component is interpreted as primary with a magnetization age of $>318 \mathrm{Ma}$ (Pastor-Galán et al., 2016). (c) Distribution of directions and VGPs and statistical parameters from both domes combined.

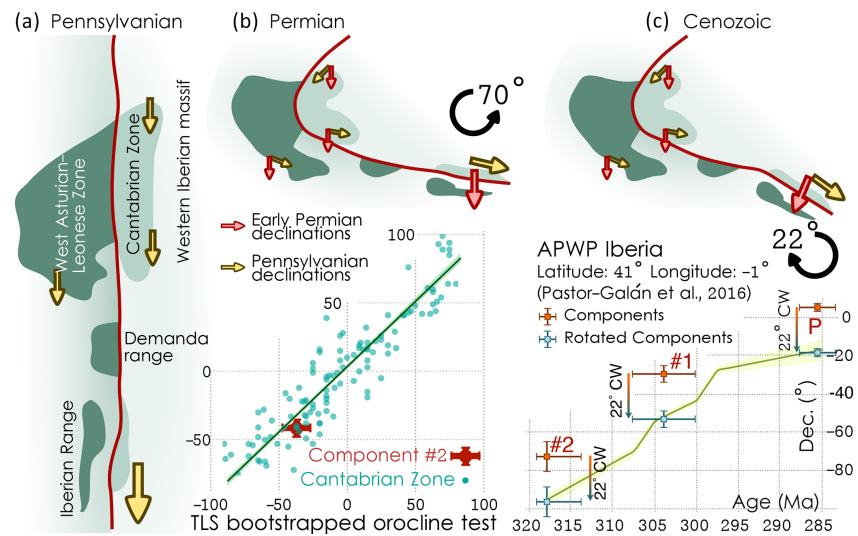

Figure 8. Cartoon depicting the different vertical-axis rotation events that occurred in the Cantabrian Zone and the Iberian Range, modified from Pastor-Galán et al. (2018). (a) Original quasilinear Variscan Orogenic belt, (b) formation of the Cantabrian Orocline around the Carboniferous-Permian boundary after a $\sim 70^{\circ}$ counterclockwise rotation in the southern branch of the Cantabrian Zone and the Iberian Range. This rotation matches the rotation for the Cantabrian Orocline; see the fit of the Iberian Range Component \#2 in the orocline test for the Cantabrian Zone (below). (c) Post-Permian (Cenozoic) rotation of $\sim 22^{\circ}$ clockwise (CW) likely produced by differential shortening during the Alpine orogeny (Izquierdo-Llavall et al., 2018). Below, the global magnetic polarity timescale for the Pennsylvanian and Cisuralian (following Ogg et al., 2016). TLS signifies total least squares. Note that once the $22^{\circ} \mathrm{CW}$ rotation in the Iberian Range is corrected, components $\# 2$, \#1, and P fit as expected with the APWP for the southern limb of the Cantabrian Orocline (Pastor-Galán et al., 2016). stones from the Central Iberian Zone, have declinations and inclinations in between the primary $318 \mathrm{Ma}$ component of the E1 granites and the post-orocline eP component (Fig. 9b). Pastor-Galán et al. (2015a, 2016) interpreted these results as being caused by a remagnetization that was acquired during the formation of the Cantabrian Orocline and that thus records intermediate steps between the component of the E1 granites and $e P$. Those authors suggest that the large amount of syn-orocline mantle-derived granitoids that intruded on the Central Iberian Zone ( $\mathrm{C} 3$ granitoids) triggered the hinterland remagnetization.

Finally, two previous studies identified an earlier magnetization in the Almadén syncline region of the SE Central Iberian Zone (Perroud et al., 1991; Parés and Van der Voo, 1992). However, Leite Mendes et al. (2020) argue that these studies are likely misinterpreted. Perroud et al. (1991), applied a complicated structural correction restoring a putative plunge of the regional structural axis to all sites, including those where the syncline axis does not plunge. Leite Mendes et al. (2020) re-sampled the syncline where its axis is subhorizontal and obtained a negative fold test, implying that the magnetization is not primary as previously interpreted. Their results, however, are similar in orientation to those components published from previous studies prior to any structural correction (Perroud et al., 1991; Parés and van der Voo, 1992).

Two additional studies sampled Laurussian margin sequences that are today adjacent to the Cantabrian Orocline region (Fig. 10). To the north, the SW part of Ireland preserves a late Paleozoic basin filled with Devonian red sandstone and Carboniferous limestone and siltstone, which was sampled by Pastor-Galán et al. (2015a). To the south are the aforementioned results from the South Portuguese Zone (Leite Mendes et al., 2020). Both areas are interpreted as 


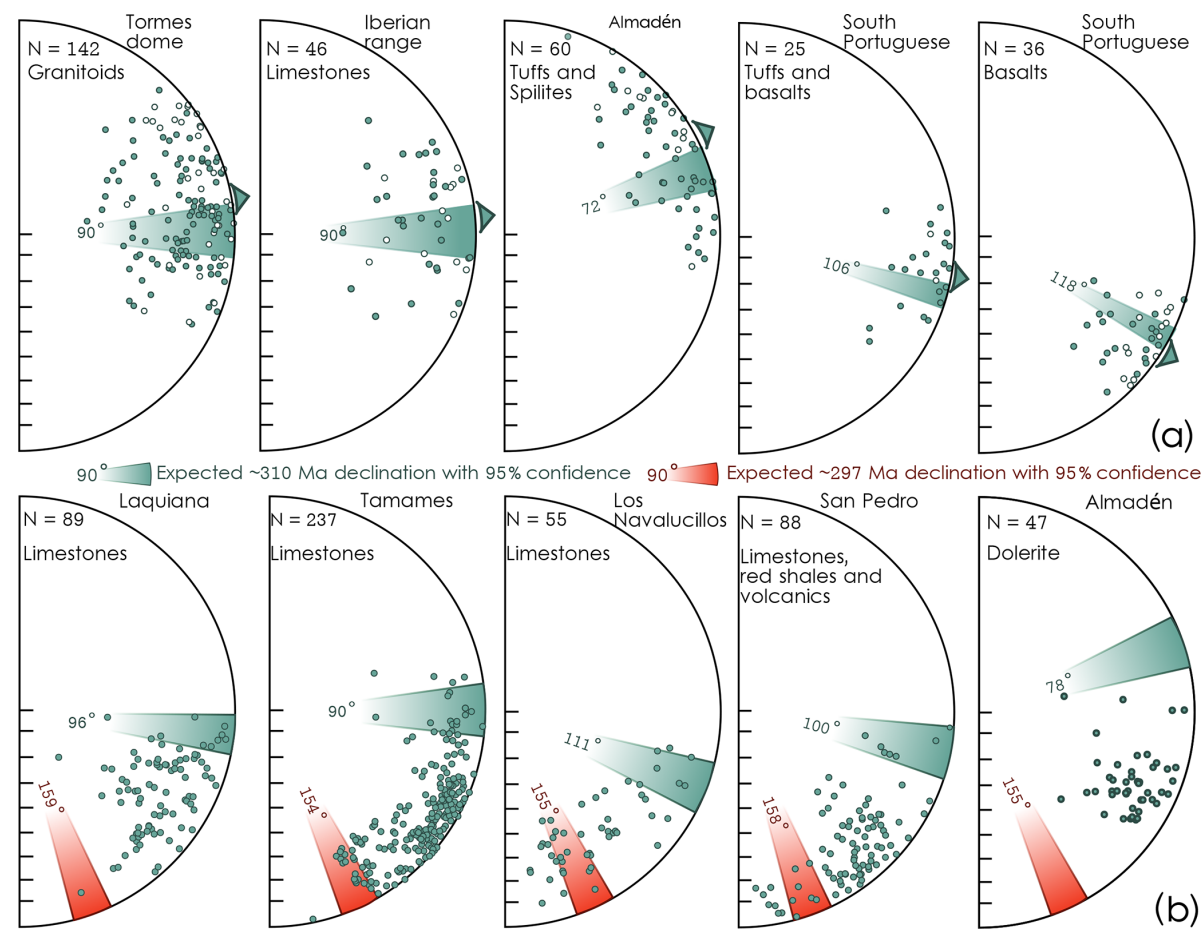

Figure 9. Compilation of the directional distributions and average declinations with an interval of confidence ( $\Delta$ Declination) in sites around the Central Iberian curve (see Fig. 6). The results show general CCW rotations in contrast to the expected CW rotations if the Central Iberian curve formed by vertical-axis rotations (see text). Results are compared with the expected declinations if those sites were part of the Cantabrian Orocline following the methodology described in Pastor-Galán et al. (2017b).

having previously been part of the Laurussian continent and therefore on the opposite side of the Rheic Ocean suture at the time of the Variscan collision (Fig. 10; e.g., Pastor-Galán et al., 2015b). In contrast, the rest of Iberia was part of, or proximal to, Gondwana (e.g., Franke et al., 2017). These Paleomagnetic results from the Laurussian margin suggest that the rotations involved in the formation of the Cantabrian Orocline occurred along both sides of the Rheic suture along its northern and southern limbs (Fig. 10a and b). Pastor-Galán et al. (2015b) hypothesized a so-called Greater Cantabrian Orocline that would have bent the entire Appalachian-Variscan orogen around a vertical axis, affecting at least the continental margins of both Gondwana and Laurussia.

\subsection{The implications of not being a secondary orocline}

The most relevant new data regarding the kinematics of the Central Iberian curve are the paleomagnetic study from the Iberian ranges (Calvín et al., 2014; Pastor-Galán et al., 2018). These results confirm that the present-day variation in trend of the tectonostratigraphic units, generally attributed to Variscan tectonics (e.g., Weil et al., 2013; Shaw et al., 2012, 2014), is likely a product of Cenozoic Alpine orogeny. Izquierdo-Llavall et al. (2019) confirmed that the interpreted Alpine rotations correspond well with the amount of shortening reconstructed in Mesozoic-Cenozoic basins.
The best preserved and most continuous outcrop in the Central Iberian's outer arc is not a Variscan structure, casting doubt that the Central Iberian curve is related to Variscan kinematics. These results are also a reminder that the regional effects of Alpine deformation are often underestimated, especially close to the major Iberian Alpine fronts: the Pyrenees, Iberian ranges, and the Betics.

Overall, new paleomagnetic data from the Central Iberian curve and nearby areas reveal pervasive late Carboniferous remagnetizations and regional vertical-axis rotations of the same sense and magnitude as those expected for the southern arm of the Cantabrian Orocline. The new paleomagnetic data indicate that a post $\sim 320 \mathrm{Ma}$ formation for the Central Iberian curve due to vertical-axis rotations is not supported (Pastor-Galán et al., 2016). The distribution in space and time of paleomagnetic results makes it unlikely that the formation of the Central Iberian curve is a product of Variscan gravitational collapse $(E 1, \sim 330-317 \mathrm{Ma})$ or concomitant to the Cantabrian Orocline (C3). So far, no pre-E2 paleomagnetic component has been found, and, consequently, paleomagnetic data cannot reject an early orogenic origin for the inner arc of the Central Iberian curve $(\mathrm{C} 1-\mathrm{C} 2$, older than $330 \mathrm{Ma})$.

From a structural geology point of view, the Central Iberian curve does not display the classic geometries and structural interference patterns found in other established oroclines (i.e., those systems that involve differential 


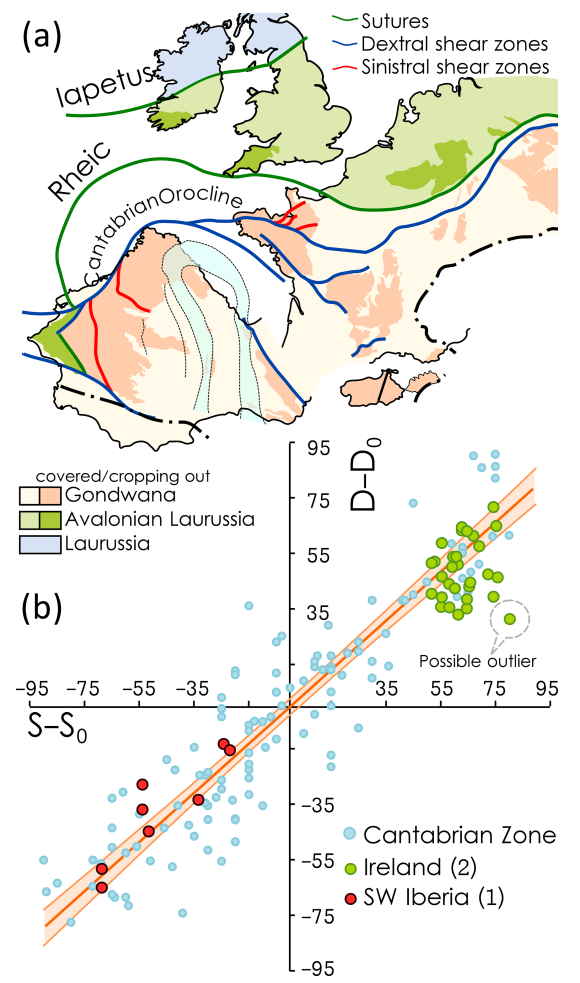

Figure 10. Orocline test of the Cantabrian Orocline (Weil et al., 2013) compared with the magnetization found in the adjacent Laurussian segments of the orogen: Ireland (Pastor-Galán et al., 2015b) and the South Portuguese Zone (Leite Mendes et al., 2020).

vertical-axis rotations; e.g., Li et al., 2012; van der Boon et al., 2018; Meijers et al., 2017; Rezaeian et al., 2020). The geometry and structural behavior of oroclines should resemble, at the crustal-scale, a regional vertical-axis fold preserved in plan view, either formed by buckling (e.g., Johnston et al., 2001) or bending (e.g., Cifelli et al., 2008) mechanisms. In oroclines, preexisting structures tend to follow fold trends around the curvature (e.g., Rosenbaum, 2014; Li et al., 2018). In addition, orocline cores tend to preserve radial structures and shortening patterns in the inner arc and orocline parallel shear zones and extensional structures in their outer arc (e.g., Ries and Shackleton, 1976; Eichelberger and McQuarrie, 2015), which is similar to what is observed in multilayer folds (e.g., Fossen, 2016).

The structural geometry of the Central Iberian curve lacks such patterns. Paleomagnetism from the Iberian ranges indicate that the Cantabrian and West Asturian-Leonese zones do not follow the Central Iberian curve; instead they continue their WNW-ESE trend into the Mediterranean in what it is now the Betic chain (Rodríguez-Cañero et al., 2018; JabaloySánchez et al., 2018; van Hinsbergen et al., 2020). Structural trends in the Ossa-Morena and the South Portuguese zones do not show any change in along-strike structural trend which supports large-scale CW rotations (e.g., Pérez-Cáceres et al., 2015; Quesada et al., 2019), whereas existing paleomagnetic data from those zones (Leite Mendes et al., 2020) support a model of $\mathrm{CCW}$ rotation associated with the broader southern arm of the Cantabrian Orocline. In the Central Iberian and Galicia-Tras-os-Montes zones, the trend of curvature is irregular (see $\mathrm{C} 1$ fold patterns in Fig. 2a) and nowhere are the expected inner and outer arc-related structures preserved (e.g., Dias da Silva et al., 2020).

The curved shape of $\mathrm{C} 1$ fold axes in the Central Iberian Zone is better explained by fold interference patterns than vertical-axis rotations (e.g., Pastor-Galán et al., 2019b). Moreover, the curved shape of the Galicia-Tras-os-Montes allochthonous nappe, which was orogen-parallel emplaced, shows no evidence of structures related to vertical-axis rotation (Fig. 2a; Dias da Silva et al., 2020). Other authors describe the changes in trend around the Central Iberian curve expressed by $\mathrm{C} 1$ folds (Fig. 2a) as the product of fold interference patterns (e.g., Gutiérrez-Alonso, 2009; PaleroFernández et al., 2015; Jacques et al., 2018b; Dias da Silva et al., 2020). Pastor-Galán et al. (2019b) showed that curved $\mathrm{C} 1$ folds in the Central Iberian Zone around the Galicia-Trasos-Montes boundary (Fig. 2a) are coaxial with $\mathrm{C} 3$ folds after restoring the effects of $\mathrm{C} 2$ and $\mathrm{E} 1$ deformation phases. Both $\mathrm{C} 1$ and $\mathrm{C} 3$ structures formed under similar shortening directions. In the same area, Jacques et al. (2018b) found similar fold interference patterns; in addition, they described kinematic incompatibility with the expected $\mathrm{CW}$ rotations that would have occurred if the Central Iberian curve had been an orocline. In other areas of the Central Iberian Zone, the curved shape of $\mathrm{C} 1$ folds has been described as an interference between $\mathrm{C} 1$ structures and their reorientation caused by C3 shear zones (Fig. 2a; e.g., Palero-Fernández et al., 2015; Dias et al., 2016) or, alternatively, by the interference between C1, C3, and E2 structures (Fig. 2a; Gutiérrez-Alonso, 2009; Arango et al., 2013; Rubio Pascual et al., 2013).

Overall, new geometric and kinematic data favor the interpretation that the Central Iberian curve is not a structure formed by differential vertical-axis rotation as was the Cantabrian Orocline but one formed as a consequence of several competing processes. It is clear from the current data that a combination of several deformation events caused the orientation of structures that today delineate the shape of the Central Iberian curve. These include (1) the northern part of the outer-arc as the product of an Alpine rigid block rotation instead of Variscan differential vertical-axis rotation (PastorGalán et al., 2018). (2) The curvature of the Galicia-Tras-osMontes allochthonous nappe reflects its original shape and could be defined as a primary curve (see Weil and Sussman, 2004) since it was orogen-parallel emplaced and preserves no evidence of vertical-axis rotations (Fig. 2a; Dias da Silva et al., 2020). (3) Structural analysis shows that fold interference patterns explain the geometry of the curved trends of Central Iberian Zone's C1 folds (Pastor-Galán et al., 2019b), whose kinematics are incompatible with the required $\mathrm{CW}$ rotations expected if the curve were an orocline (Jacques et al., 2018b). 


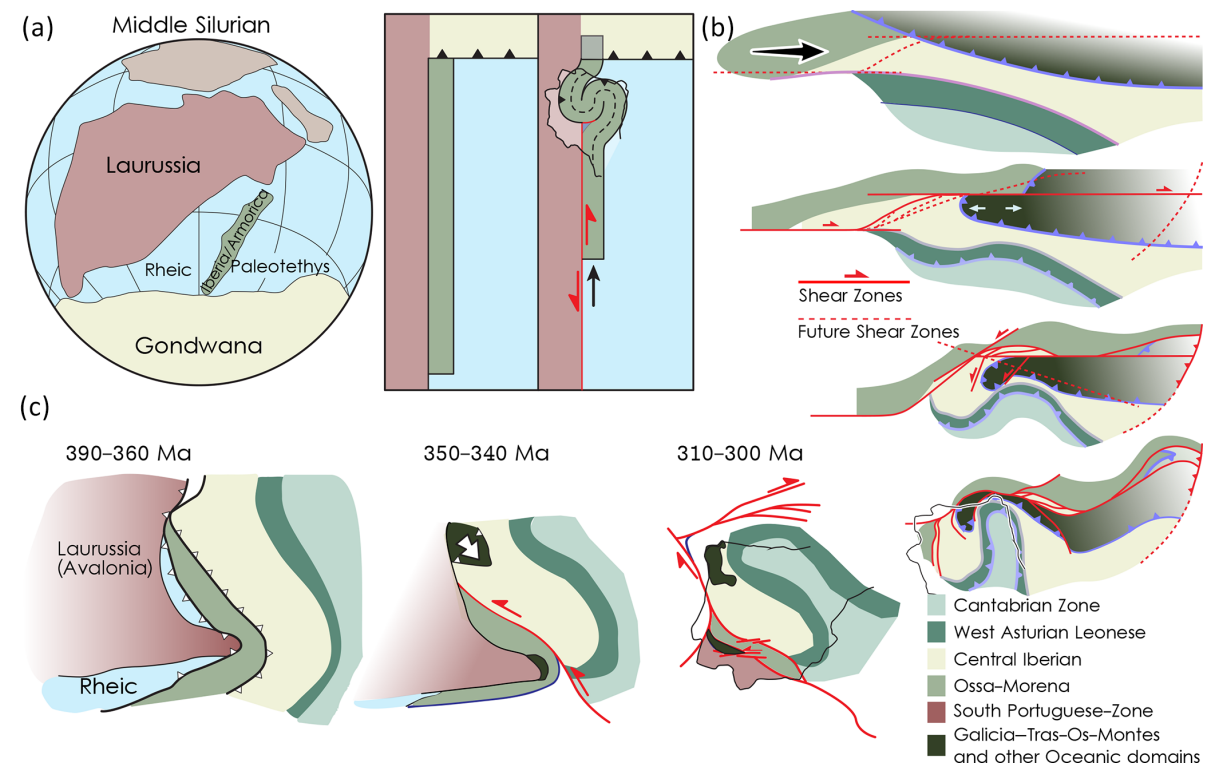

Figure 11. Pioneering hypotheses for the Central Iberian curve. Note that none of them fulfill the most recent geometric and kinematic criteria. (a) Simplified ribbon continent model from Johnston et al. (2013) and Shaw and Johnston (2016). (b) Dextral mega-shear model from Martínez Catalán (2011). (c) Kinematic model with indentation and left-lateral shearing from Simancas et al. (2013).

\section{Get Back: Ideas flowing out and endless questions}

The pioneering works in the last decade that resurrected the idea of a Central Iberian curve speculated that both the Cantabrian and Central Iberian zones buckled together as secondary oroclines (Fig. 11; Martínez Catalán, 2011; Shaw et al., 2012, 2014; Shaw and Johnston, 2016; Carreras and Druguet, 2014). Later, Martínez Catalán et al. (2014) and Díez Fernández and Pereira (2017) reformulated the hypothesis of Martínez Catalán (2011) and proposed that the Central Iberian curve formed as an orocline between 315 and $305 \mathrm{Ma}$, assigning the Cantabrian Orocline a time frame between 305 and $295 \mathrm{Ma}$ (Fig. 11). The proposed tectonic mechanisms to support these early kinematic models are varied: (1) buckling of a ribbon "Armorican" continent (Fig. 11a; Shaw et al., 2014, 2016); (2) buckling of a completely formed Variscan orogen during a putative "Pangea B" to "Pangea A" transition in the late Carboniferous (Fig. 11b; Carreras and Druguet, 2014; Martínez Catalán, 2011); and (3) indentation of Laurussia into Gondwana during the early stages of collision (in present-day southwestern Iberia, South Portuguese Zone), producing first the Central Iberian curve as a mega-drag fold during Carboniferous times and then slightly later the Cantabrian Orocline as a consequence of an indentation process (Fig. 11c; Simancas et al., 2013).

The reviewed data in Sects. 4 and 5 contradict the aforementioned hypotheses. Paleomagnetism and structural patterns (Sect. 5; Figs. 6-11) disagree with the necessary CW rotations required to support a late Carboniferous orocline origin for the Central Iberian curve (models in Fig. 11a and b). In addition, the sense and magnitude of the vertical-axis rotations observed in southwestern Iberia (Fig. 10) imply that the South Portuguese (Avalonian segment) and OssaMorena zones moved together with the southern limb of the Cantabrian Orocline during the Pennsylvanian and early Permian. This means that the South Portuguese Zone was already parallel to the general trend of the Variscan orogen prior to the Cantabrian Orocline formation, implying the lack of a Laurussian rigid indenter into Gondwana (e.g., Simancas et al., 2013). This discrepancy leaves orogen-parallel terrane transport as a possible explanation for the kinematics observed in the Ossa-Morena and South-Portuguese zones (e.g., Pérez-Cáceres et al., 2016). At the same time, paleomagnetism from southwestern Iberia supports the hypothesis of a Greater Cantabrian Orocline that extended into both Gondwana and Laurussia in its northern and southern limbs (Fig. 10; Pastor-Galán et al., 2015b).

In spite of the kinematic constraints and structural patterns that do not support a vertical-axis origin for the Central Iberian curve in the late Carboniferous, there are geometric constraints that remain challenging to account for. For example, the curved shape of the aeromagnetic and gravity anomalies of Iberia are real (Fig. 5). These striking patterns could be due to Variscan-Alpine structural interference, as suggested for the Iberian ranges, but currently there is not enough data to rigorously test this hypothesis. In addition, there are the curved traces of $\mathrm{C} 1$ fold-axes, whose geometry and kinematics are reasonably well constrained around Galicia-Tras-osMontes (e.g., Dias da Silva et al., 2020), but in many other areas their strong curvature remains largely unstudied (Fig. 2), and, therefore, to date we can only speculate on their origin. 
(a) Pre C1 ( 380 Ma)

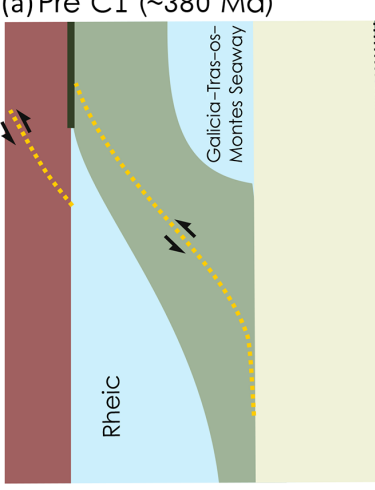

(d) C3 ( 315-300 Ma)

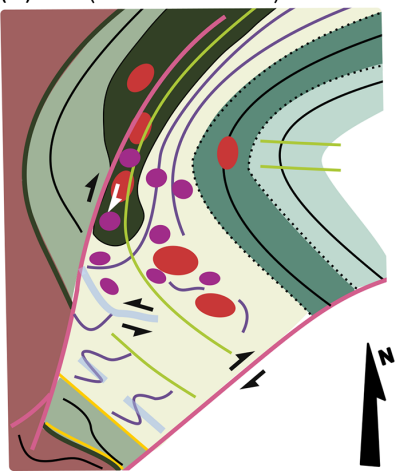

(b) $\mathrm{C} 1-\mathrm{C} 2(\sim 360-335 \mathrm{Ma})$

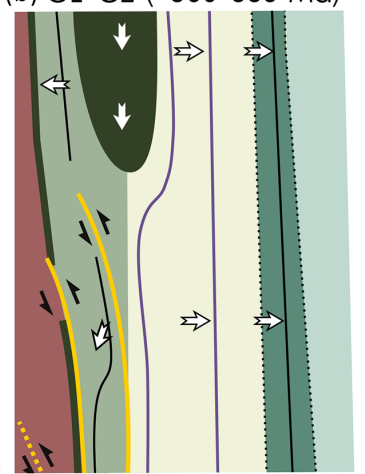

(e) C4-E2 ( 300-280 Ma)

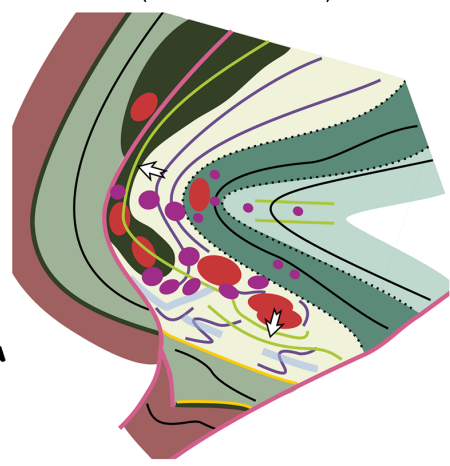

(c) E1 ( 330-317 Ma)

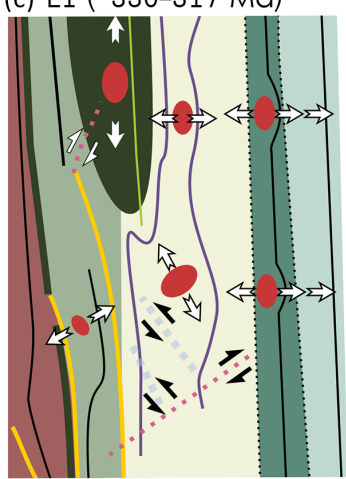

Cantabrian Zone

West Asturian-Leonese

Central Iberian

Ossa-Morena

South Portuguese-Zone

Galicia-Tras-Os-Montes

and other Oceanic domains

E1/E2 gneiss domes \& granites

C3-C4 mantle derived granitoids

- C3 Dextral shear zones

- C3 S Sinistral shear zones

C $1 / \mathrm{C} 2$ Sinistral shear zones

- Folds trend

E1/C3 folds Central Iberian

- $\mathrm{C} 1 / \mathrm{C} 2$ folds Central Iberian

... Zone boundary

is Transport direction

Figure 12. Preliminary kinematic proposal for the Iberian Variscides. (a) Pre-collisional stage after the opening of the Galicia-Tras-osMontes restricted seaway (e.g., Pin et al., 2002; Gutiérrez-Alonso et al., 2008a; Arenas et al., 2016). The irregular shape of the margin and the younging westward deformation front (e.g., Dallmeyer et al., 1997) resulted in tectonic escape towards the still open Rheic Ocean (e.g., Braid et al., 2011; Murphy et al., 2016). (b) After closure of the Rheic Ocean, C1 and C2 structures formed. The Galicia-Tras-os-Montes was orogen-parallel emplaced (e.g., Martínez Catalán, 1990; Dias da Silva et al., 2020), preserving the shape of the seaway (i.e., a primary arc). (c) The gravitational collapse of the orogen produced widespread anatexis and fold interference in the hinterland and the emplacement of the foreland fold-and-thrust belt. (d) In Pennsylvanian times, a change in the far-field stress buckled the Variscan belt around a vertical axis (for details see Gutiérrez-Alonso et al., 2008a; Weil et al., 2013; Pastor-Galán et al., 2015a), creating new interference patterns and a lithospheric-scale response (see Gutiérrez-Alonso et al., 2004, 2011a; Pastor-Galán et al., 2012a). (e) When the orocline became too tight to keep rotating, new cross-cutting brittle structures (C4) formed and minor extensional collapse (E2) occurred (e.g., Fernández-Lozano et al., 2019; Dias da Silva et al., 2020).

Shaw et al. (2012) supported their hypothesis of a secondary orocline by assuming that paleocurrents were parallel through Iberia during Ordovician times. However, some of the observed deflections in the paleocurrents studied by Shaw et al. (2012; see Fig. 3) are also explained by Alpine vertical-axis rotations (the case of the Iberian ranges) and fold interference patterns (SE of the Central Iberian Zone). Others (center and SW of the Central Iberian Zone) may be explained by a local response to basin architecture (Fig. 3), where paleoflow directions would trend toward the deepest basin troughs. The Ordovician basin architecture of Iberia allows for opposite directed paleocurrents from both sides of such troughs (Fig. 3). However, the early Paleozoic basin architecture in Iberia and their local deformation events require further research (Sánchez-García et al., 2019).

Finally, although kinematic evidence is still scarce for the earliest pre-Variscan and early Variscan events, we argue that pre-orogenic physiographic features, such as the opening of a marginal restricted ocean between Gondwana and its distal platform at $395 \mathrm{Ma}$ (Fig. 12a; Pin et al., 2002; Gutiérrez-Alonso et al., 2008b; Arenas et al., 2016), explain the rounded shape of the Galicia-Tras-os-Montes curve as a primary curve. During the collision, the irregular shape of the Galicia-Tras-os-Montes seaway would cause the orogenparallel emplacement of allochthonous nappes (Fig. 12b; Dias da Silva et al., 2020) and the sinistral movements of the Ossa-Morena and South Portuguese zones in southwestern Iberia (Fig. 13a, b, c; Quesada et al., 2019). During the late Carboniferous, possibly due to a plate reorganization during the final amalgamation of Pangea (Fig. 12d; e.g., GutiérrezAlonso et al., 2008a; Pastor-Galán et al., 2015a), the farfield stress field likely changed, which caused the entire orogen to buckle around a vertical axis (Gutiérrez-Alonso et al., 
2004), including both the Gondwana and Laurussia margins (Fig. 12e; Pastor-Galán et al., 2015b).

Data availability. The availability of the previous data is stored in the corresponding repositories of each paper or in the papers themselves.

Author contributions. DPG is responsible for data curation and visualization in the paper. All authors contributed equally to the discussion of ideas and to the writing of the paper at all stages.

Competing interests. The authors declare that they have no conflict of interest.

Special issue statement. This article is part of the special issue "The Iberian Massif in the frame of the European Variscan Belt". It is not associated with a conference.

Acknowledgements. Daniel Pastor-Galán thanks the extraordinary hard work, patience, and endurance of the Utrecht University students that embraced and enjoyed studying the kinematics of the Central Iberian curve: Thomas Groenewegen, Bart Ursem, Daniel Brower, Mark Diederen, and Bruno LeiteMendes. Daniel Pastor-Galán thanks FRIS and CNEAS for the continuous financial support. This paper is a contribution to the IGCP no. 648 "Supercontinent Cycles and Global Geodynamics". Fifty years ago four fabulous guys let it be and never got back.

Financial support. This research has been supported by the Spanish Ministry of Science, Innovation and Universities (grant no. PGC2018-096534-B-I00) and the Russian Federation Government (grant no. 14.Y26.31.0012).

Review statement. This paper was edited by Ícaro Dias da Silva and reviewed by Dominique Jacques and one anonymous referee.

\section{References}

Ábalos, B., Carreras, J., Druguet, E., Escuder Viruete, J., Gómez Pugnaire, M. T., Lorenzo Álvarez, S., Quesada, C., Rodríguez Fernández, L. R., and Gil-Ibarguchi, J. I.: Variscan and preVariscan tectonics, in: The geology of Spain, edited by: Gibbons, W. and Moreno, T., Geological Society of London, London, 155183, 2002.

Aerden, D.: Correlating deformation in Variscan NW-Iberia using porphyroblasts; implications for the Ibero-Armorican Arc, J. Struct. Geol., 26, 177-196, 2004.

Alcock, J. E., Catalán, J. R. M., Arenas, R., and Montes, A. D.: Use of thermal modeling to assess the tectonometamorphic history of the Lugo and Sanabria gneiss domes, Northwest Iberia, B. Soc. Geol. Fr., 180, 179-197, https://doi.org/10.2113/gssgfbull.180.3.179, 2009.

Aller, J., Bastida, F., and Bobillo-Ares, N. C.: On the development of kink-bands: A case study in the West Asturian-Leonese Zone (Variscan belt, NW Spain)/Sur le développement des kinkbands?: un exemple dans le Zone Astur Occidentale-léonaise (chaîne varisque ibérique, nord-ouest de l'Espagne), B. Soc. Geol. Fr., 191, 6, https://doi.org/10.1051/bsgf/2020003, 2020.

Aller, J. J. J. and Gallastegui, J. J.: Analysis of kilometricscale superposed folding in the Central Coal Basin (Cantabrian zone, NW Spain), J. Struct. Geol., 17, 961-969, https://doi.org/10.1016/0191-8141(94)00115-G, 1995.

Alonso, J. L., Marcos, A., and Suárez, A.: Paleogeographic inversion resulting from large out of sequence breaching thrusts: The León Fault (Cantabrian zone, NW Iberia). A new picture of the external Variscan thrust belt in the Ibero-Armorican arc, Geol. Acta, 7, 451-473, https://doi.org/10.1344/105.000001449, 2009.

Álvaro, J. J., Casas, J. M., Clausen, S., and Quesada, C.: Early Palaeozoic geodynamics in NW Gondwana, J. Iber. Geol., 44, 551-565, https://doi.org/10.1007/s41513-018-0079-x, 2018.

Ardizone, J., Mezcua, J., and Socías, I.: Mapa aeromagnético de España peninsular, Instituto Geográfico Nacional, Spain, 1989.

Aramburu, C., Méndez-Bedia, I., and Arbizu, M.: The Lower Palaeozoic in the Cantabrian Zone (Cantabrian Mountains, NW Spain), in: Paleozoic conodonts from north Spain, edited by: García-López, S. and Bastida, F., Cuad Mus Geomin, 1, 35-49, Madrid, Spain, 2002.

Arango, C., Díez Fernández, R., and Arenas, R.: Large-scale flatlying isoclinal folding in extending lithosphere: Santa María de la Alameda dome (Central Iberian Massif, Spain), Lithosphere, 5, 483-500, https://doi.org/10.1130/L270.1, 2013.

Arenas, R., Sánchez Martínez, S., Díez Fernández, R., Gerdes, A., Abati, J., Fernández-Suárez, J., Andonaegui, P., González Cuadra, P., López Carmona, A., Albert, R., Fuenlabrada, J. M., and Rubio Pascual, F. J.: Allochthonous terranes involved in the Variscan suture of NW Iberia: A review of their origin and tectonothermal evolution, Earth-Sci. Rev., 161, 140-178, https://doi.org/10.1016/j.earscirev.2016.08.010, 2016.

Ayala, C., Bohoyo, F., Maestro, A., Reguera, M. I., Torne, M., Rubio, F., Fernàndez, M., and García-Lobón, J. L.: Updated Bouguer anomalies of the Iberian Peninsula: a new perspective to interpret the regional geology, J. Maps, 12, 1089-1092, https://doi.org/10.1080/17445647.2015.1126538, 2016.

Ayarza, P., Catalan, J. R. M., Gallart, J., Pulgar, J. A., and Danobeitia, J. J.: Estudio Sismico de la Corteza Iberica Norte 3.3: A seismic image of the Variscan crust in the hinterland of the NW Iberian Massif, Tectonics, 17, 171-186, https://doi.org/10.1029/97TC03411, 1998.

Azor, A., Rubatto, D., Simancas, J. F., Lodeiro, F. G., Poyatos, D. M., Parra, L. M. M., and Matas, J.: Rheic Ocean ophiolitic remnants in Southern Iberia questioned by SHRIMP U-Pb zircon ages on the Beja-Acebuches amphibolites, Tectonics, 27, C5006, https://doi.org/10.1029/2008TC002306, 2008.

Azor, A., Dias da Silva, Í., Gómez Barreiro, J., González-Clavijo, E., Martínez Catalán, J. R., Simancas, J. F., Martínez Poyatos, D., Pérez-Cáceres, I., González Lodeiro, F., Expósito, I., Casas, J. M., Clariana, P., García-Sansegundo, J., and Margalef, A.: Deformation and Structure, in: The Geology of Iberia: A Geodynamic 
Approach, edited by: Quesada, C. and Oliveira, J. T., 307-348, Springer International Publishing, Cham., 2019.

Barrois, C. E.: Recherches sur le terrains anciens des Asturies et de la Galice, Six-Horemans, Lille, 1882.

Bastida, F.: Zona Cantábrica, in: Geología de España, edited by: Vera, J. A., 25-49, SGE-IGME, Madrid, 2004.

Bayona, G., Thomas, W. A., and Van der Voo, R.: Kinematics of thrust sheets within transverse zones: A structural and paleomagnetic investigation in the Appalachian thrust belt of Georgia and Alabama, J. Struct. Geol., 25, 1193-1212, https://doi.org/10.1016/S0191-8141(02)00162-1, 2003.

Braid, J. A., Murphy, J. B., Quesada, C., and Mortensen, J.: Tectonic escape of a crustal fragment during the closure of the Rheic Ocean: U-Pb detrital zircon data from the Late Palaeozoic Pulo do Lobo and South Portuguese zones, southern Iberia, J. Geol. Soc., 168, 383-392, 2011.

Buiter, S. J. H. and Torsvik, T. H.: A review of Wilson Cycle plate margins: A role for mantle plumes in continental break-up along sutures?, Gondwana Res., 26, 627-653, https://doi.org/10.1016/j.gr.2014.02.007, 2014.

Butler, R. F.: Paleomagnetism: Magnetic domains to geologic terranes, Electronic Edn. 23, available at: https://websites.pmc.ucsc. edu/ njarboe/pmagresource/ButlerPaleomagnetismBook.pdf (last access: 3 July 2020), 1998.

Calvín, P., Casas, A. M., Villalaín, J. J., Tierz, P., Calvín, P., Casas, A. M., Villalaín, J. J., Tierz, P., Calvin, P., Casas, A. M., Villalaín, J. J., and Tierz, P.: Reverse magnetic anomaly controlled by Permian Igneous rocks in the Iberian Chain (N Spain), Geol. Acta, 12, 193-207, https://doi.org/10.1344/GeologicaActa2014.12.3.2, 2014.

Calvín, P., Casas-Sainz, A. M. M., Villalaín, J. J. J., and Moussaid, B.: Diachronous folding and cleavage in an intraplate setting (Central High Atlas, Morocco) determined through the study of remagnetizations, J. Struct. Geol., 97, 144-160, https://doi.org/10.1016/j.jsg.2017.02.009, 2017.

Calvín-Ballester, P. and Casas, A.: Folded Variscan thrusts in the Herrera Unit of the Iberian Range (NE Spain), Geol. Soc. Lond. Spec. Publ., 394, 39-52, https://doi.org/10.1144/SP394.3, 2014.

Carey, S. W.: The orocline concept in geotectonics - Part I, Pap. Proc. R. Soc. Tasman., 89, 255-288, 1955.

Carreras, J. and Druguet, E.: Framing the tectonic regime of the NE Iberian Variscan segment, Geol. Soc. Lond. Spec. Publ., 405, 249-264, https://doi.org/10.1144/SP405.7, 2014.

Chopin, F., Schulmann, K., Skrzypek, E., Lehmann, J., Dujardin, J. R., Martelat, J. E., Lexa, O., Corsini, M., Edel, J. B., Štípská, P., and Pitra, P.: Crustal influx, indentation, ductile thinning and gravity redistribution in a continental wedge: Building a Moldanubian mantled gneiss dome with underthrust Saxothuringian material (European Variscan belt), Tectonics, 31, TC1013, https://doi.org/10.1029/2011TC002951, 2012.

Chopin, F., Corsini, M., Schulmann, K., El Houicha, M., Ghienne, J.-F., and Edel, J.-B.: Tectonic evolution of the Rehamna metamorphic dome (Morocco) in the context of the Alleghanian-Variscan orogeny, Tectonics, 33, 1154-1177, https://doi.org/10.1002/2014TC003539, 2014.

Cifelli, F., Mattei, M., and Della Seta, M.: Calabrian Arc oroclinal bending: The role of subduction, Tectonics, 27, TC5001, https://doi.org/10.1029/2008TC002272, 2008.
Crespo-Blanc, A. and Orozco, M.: The Southern Iberian Shear Zone: a major boundary in the Hercynian folded belt, Tectonophysics, 148, 221-227, 1988.

Dallmeyer, R. D., Fonseca, P. E., Quesada, C., and Ribeiro, A.: ${ }^{40} \mathrm{Ar} /{ }^{39} \mathrm{Ar}$ mineral age constraints for the tectonothermal evolution of a Variscan suture in southwest Iberia, Tectonophysics, 222, 177-194, https://doi.org/10.1016/0040-1951(93)90048-O, 1993.

Dallmeyer, R. D. D., Catalán, J. R. M., Arenas, R., Gil Ibarguchi, J. I. I., Gutiérrez-Alonso, G., Farias, P., Bastida, F., and Aller, J.: Diachronous Variscan tectonothermal activity in the NW Iberian Massif: Evidence from ${ }^{40} \mathrm{Ar} /{ }^{39} \mathrm{Ar}$ dating of regional fabrics, Tectonophysics, 277, 307-337, https://doi.org/10.1016/S00401951(97)00035-8, 1997.

Del Greco, K., Johnston, S. T., Gutiérrez-Alonso, G., Shaw, J., and Lozano, J. F.: Interference folding and orocline implications: A structural study of the Ponga Unit, Cantabrian orocline, northern Spain, Lithosphere, 8, 757-768, https://doi.org/10.1130/L576.1, 2016.

del Moral, B. and Sarmiento, G. N.: Conodontos del Katiense (Ordovícico Superior) del sector meridional de la Zona Centroibérica (España), Rev. Esp. Micropaleontol., 40, 169-245, 2008.

Dias, R. and Ribeiro, A.: Finite strain analysis in a transpressive regime (Variscan autochthon, northeast Portugal), Tectonophysics, 191, 389-397, https://doi.org/10.1016/00401951(91)90069-5, 1991.

Dias, R. and Ribeiro, A.: Constriction in a transpressive regime an example in the Iberian branch of the Ibero-Armorican arc, J. Struct. Geol., 16, 1543-1554, 1994.

Dias, R., Mateus, A., and Ribeiro, A.: Strain partitioning in transpressive shears zones in the southern branch of the Variscan Ibero-Armorican arc: Geodin. Acta, 16, 119-129, https://doi.org/10.1016/j.geoact.2003.04.001, 2003.

Dias, R., Ribeiro, A., Romão, J., Coke, C., and Moreira, N.: A review of the arcuate structures in the Iberian Variscides; constraints and genetic models, Tectonophysics, 681, 170-194, https://doi.org/10.1016/j.tecto.2016.04.011, 2016.

Dias da Silva, Í., Valverde-Vaquero, P., González-Clavijo, E., DíezMontes, A., and Catalán, J. R. M.: Structural and stratigraphical significance of $\mathrm{U}-\mathrm{Pb}$ ages from the Mora and Saldanha volcanic complexes (NE Portugal, Iberian Variscides), Geol. Soc. Lond. Spec. Publ., 405, 115-135, https://doi.org/10.1144/SP405.3, 2014.

Dias da Silva, Í., Linnemann, U., Hofmann, M., González-Clavijo, E., Díez-Montes, A., and Catalán, J. R. M.: Detrital zircon and tectonostratigraphy of the Parautochthon under the Morais Complex (NE Portugal): implications for the Variscan accretionary history of the Iberian Massif, J. Geol. Soc., 172, 45-61, https://doi.org/10.1144/jgs2014-005, 2015.

Dias da Silva, Í., Gómez-Barreiro, J., Martínez Catalán, J. R., Ayarza, P., Pohl, J., and Martínez, E.: Structural and microstructural analysis of the Retortillo Syncline (Variscan belt, Central Iberia). Implications for the Central Iberian Orocline, Tectonophysics, 717, 99-115, https://doi.org/10.1016/j.tecto.2017.07.015, 2017.

Dias da Silva, I., Pereira, M. F., Silva, J. B., and Gama, C.: Time-space distribution of silicic plutonism in a gneiss dome of the Iberian Variscan Belt: The Évora Massif (Ossa- 
Morena Zone, Portugal), Tectonophysics, 747-748, 298-317, https://doi.org/10.1016/j.tecto.2018.10.015, 2018.

Dias da Silva, Í., González Clavijo, E., and Díez-Montes, A.: The collapse of the Variscan belt: a Variscan lateral extrusion thin-skinned structure in NW Iberia, Int. Geol. Rev., https://doi.org/10.1080/00206814.2020.1719544, online first, 2020.

Díez Balda, M. A.: El Complejo Esquisto-Grauváquico, las series paleozoicas y la estructura hercínica al Sur de Salamanca, Acta Salmanticensia, 52, 1-162, 1986.

Díez Balda, M. A., Vegas, R., and González Lodeiro, F.: CentralIberian zone structure, in: Pre-mesozoic geology of Iberia, edited by: Dallmeyer, R. D. and Martinez Garcia, E., Springer Science \& Business, Berlin Heiderlberg, 172-188, 1990.

Díez Balda, M. A., Martínez Catalán, J. R., and Ayarza Arribas, P.: Syn-collisional extensional collapse parallel to the orogenic trend in a domain of steep tectonics: the Salamanca Detachment Zone (Central Iberian Zone, Spain), J. Struct. Geol., 17, 163182, https://doi.org/10.1016/0191-8141(94)E0042-W, 1995.

Díez Fernández, R. and Arenas, R.: The Late Devonian Variscan suture of the Iberian Massif: A correlation of high-pressure belts in NW and SW Iberia, Tectonophysics, 654, 96-100, https://doi.org/10.1016/j.tecto.2015.05.001, 2015.

Díez Fernández, R. and Pereira, M. F.: Extensional orogenic collapse captured by strike-slip tectonics: Constraints from structural geology and $\mathrm{UPb}$ geochronology of the Pinhel shear zone (Variscan orogen, Iberian Massif), Tectonophysics, 691, 290310, https://doi.org/10.1016/j.tecto.2016.10.023, 2016.

Díez Fernández, R. and Pereira, M. F.: Strike-slip shear zones of the Iberian Massif: Are they coeval?, Lithosphere, 9, 726-744, https://doi.org/10.1130/L648.1, 2017.

Díez Fernández, R., Gómez Barreiro, J., Martínez Catalán, J. R., and Ayarza, P.: Crustal thickening and attenuation as revealed by regional fold interference patterns: Ciudad Rodrigo basement area (Salamanca, Spain), J. Struct. Geol., 46, 115-128, https://doi.org/10.1016/j.jsg.2012.09.017, 2013.

Díez Fernández, R., Arenas, R., Pereira, M. F., Sánchez-Martínez, S., Albert, R., Martín Parra, L.-M., Rubio Pascual, F.-J., and Matas, J.: Tectonic evolution of Variscan Iberia: GondwanaLaurussia collision revisited, Earth-Sci. Rev., 162, 269-292, https://doi.org/10.1016/j.earscirev.2016.08.002, 2016.

Díez-Montes, A., Martínez Catalán, J. R. R., and BellidoMulas, F.: Role of the Ollo de Sapo massive felsic volcanism of NW Iberia in the Early Ordovician dynamics of northern Gondwana, Gondwana Res., 17, 363-376, https://doi.org/10.1016/j.gr.2009.09.001, 2010.

Domeier, M. and Torsvik, T. H.: Plate tectonics in the late Paleozoic, Geosci. Front., 5, 303-350, https://doi.org/10.1016/j.gsf.2014.01.002, 2014.

Du Toit, A. L.: Our wandering continents: an hypothesis of continental drifting, Oliver and Boyd, available at: http://books.google.es/books?id=iDZEAAAAIAAJ (last access: 3 July 2020), 1937.

Edel, J. B., Schulmann, K., Lexa, O., and Lardeaux, J. M.: Late Palaeozoic palaeomagnetic and tectonic constraints for amalgamation of Pangea supercontinent in the European Variscan belt, Earth-Sci. Rev., 177, 589-612, https://doi.org/10.1016/j.earscirev.2017.12.007, 2018.
Eichelberger, N. and McQuarrie, N.: Kinematic reconstruction of the Bolivian orocline, Geosphere, 11, 445-462, https://doi.org/10.1130/GES01064.1, 2015.

Escuder Viruete, J., Arenas, R., and Catalán, J. R. M.: Tectonothermal evolution associated with Variscan crustal extension in the Tormes Gneiss Dome (NW Salamanca, Iberian Massif, Spain), Tectonophysics, 238, 117-138, https://doi.org/10.1016/00401951(94)90052-3, 1994.

Farias, P., Gallastegui, G., González Lodeiro, F., Marquínez, J., Martín Parra, L. M., Martínez Catalán, J. R., Pablo Maciá, J. D., and Rodríguez Fernández, L. R.: Aportaciones al conocimiento de la litoestratigrafía y estructura de Galicia Central, Memórias da Faculdade de Ciências, Universidade do Porto, 1, 411-431, 1987.

Fernández-Lozano, J., Pastor-Galán, D., Gutiérrez-Alonso, G., and Franco, P.: New kinematic constraints on the Cantabrian orocline: A paleomagnetic study from the Peñalba and Truchas synclines, NW Spain, Tectonophysics, 681, 195-208, https://doi.org/10.1016/j.tecto.2016.02.019, 2016.

Fernández-Lozano, J., Gutiérrez-Alonso, G., Willingshofer, E., Sokoutis, D., de Vicente, G., and Cloetingh, S.: Shaping of intraplate mountain patterns: The Cantabrian orocline legacy in Alpine Iberia, Lithosphere, 11, 708-721, https://doi.org/10.1130/L1079.1, 2019.

Fernández-Suárez, J., Gutiérrez-Alonso, G., Pastor-Galán, D., Hofmann, M., Murphy, J. B., and Linnemann, U.: The EdiacaranEarly Cambrian detrital zircon record of NW Iberia: Possible sources and paleogeographic constraints, Int. J. Earth Sci., 103, 1335-1357, https://doi.org/10.1007/s00531-013-0923-3, 2014.

Fossen, H.: Structural Geology, Cambridge University Press, Cambridge, UK, 2016.

Franke, W., Cocks, L. R. M., and Torsvik, T. H.: The Palaeozoic Variscan oceans revisited, Gondwana Res., 48, 257-284, https://doi.org/10.1016/j.gr.2017.03.005, 2017.

Franke, W., Cocks, L. R. M., and Torsvik, T. H.: Detrital zircons and the interpretation of palaeogeography, with the Variscan Orogeny as an example, Geol. Mag., 157, 690-694, https://doi.org/10.1017/S0016756819000943, 2020.

García-Arias, M., Díez-Montes, A., Villaseca, C., and Blanco-Quintero, I. F.: The Cambro-Ordovician Ollo de Sapo magmatism in the Iberian Massif and its Variscan evolution: A review, Earth-Sci. Rev., 176, 345-372, https://doi.org/10.1016/j.earscirev.2017.11.004, 2018.

Gil Toja, A., Jimenez-Ontiveros, P., and Seara Valero, J. R.: La cuarta fase de deformación hercinica en la Zona Centroibérica del Macizo Hespérico: Cuadernos Del Laboratório Xeoloxico De Laxe, 9, 91-104, 1985.

Gong, Z., Langereis, C. G., and Mullender, T. A. T.: The rotation of Iberia during the Aptian and the opening of the Bay of Biscay, Earth Planet. Sc. Lett., 273, 80-93, 2008.

Gozalo, R., Liñán, E., Vintaned, J. A. G., Eugenia, M., Álvarez, D., Martorell, J. B. C., Zamora, S., Esteve, J., and Mayoral, E.: The Cambrian of the Cadenas Ibéricas (ne Spain) and Its Trilobites, Cuadernos del Museo Geominero, 9, 137-151, 2008.

Gutiérrez-Alonso, G.: El Antiforme del Narcea y su relación con los mantos occidentales de la Zona Cantábrica, $\mathrm{PhD}$ thesis, Universidad de Oviedo, 1992. 
Gutiérrez-Alonso, G.: Strain partitioning in the footwall of the Somiedo Nappe: Structural evolution of the Narcea Tectonic window, NW Spain, J. Struct. Geol., 18, 1217-1229, 1996.

Gutiérrez Alonso, G.: Estratigrafía y Tectónica, in: Memoria del Mapa Geológico de España 1:50000, Hoja de Mora (680), IGME, Madrid, available at: http://info.igme.es/ cartografiadigital/datos/magna50/memorias/MMagna0658.pdf (last access: 3 July 2020), 2009.

Gutiérrez-Alonso, G., Fernández-Suárez, J., and Weil, A. B.: Orocline triggered lithospheric delamination, in: Special Paper 383: Orogenic curvature: Integrating paleomagnetic and structural analyses, Vol. 383, edited by: Weil, A. B. and Sussman, A., 121130, Geological Society of America, Boulder, 2004.

Gutiérrez-Alonso, G., Fernández-Suárez, J., Weil, A. B., Brendan Murphy, J., Damian Nance, R., Corf, F., and Johnston, S. T.: Selfsubduction of the Pangaean global plate, Nat. Geosci., 1, 549553, https://doi.org/10.1038/ngeo250, 2008a.

Gutiérrez-Alonso, G., Murphy, J. B. B., Fernández-Suárez, J., and Hamilton, M. A. A.: Rifting along the northern Gondwana margin and the evolution of the Rheic Ocean: A Devonian age for the El Castillo volcanic rocks (Salamanca, Central Iberian Zone), Tectonophysics, 461, 157-165, https://doi.org/10.1016/j.tecto.2008.01.013, 2008b.

Gutiérrez-Alonso, G., Fernández-Suárez, J., Jeffries, T. E. T. E. E., Johnston, S. T., Pastor-Galán, D., Murphy, J. B. B., Franco, M. P. P., and Gonzalo, J. C. C.: Diachronous post-orogenic magmatism within a developing orocline in Iberia, European Variscides, Tectonics, 30, TC5008, https://doi.org/10.1029/2010TC002845, 2011a.

Gutiérrez-Alonso, G., Murphy, J. B., Fernández-Suárez, J., Weil, A. B., Franco, M. P., and Gonzalo, J. C.: Lithospheric delamination in the core of Pangea: Sm-Nd insights from the Iberian mantle, Geology, 39, 155-158, https://doi.org/10.1130/G31468.1, 2011 b.

Gutiérrez-Alonso, G., Collins, A. S., Fernández-Suárez, J., Pastor-Galán, D., González-Clavijo, E., Jourdan, F., Weil, A. B., and Johnston, S. T.: Dating of lithospheric buckling: ${ }^{40} \mathrm{Ar} /{ }^{39} \mathrm{Ar}$ ages of syn-orocline strike-slip shear zones in northwestern Iberia, Tectonophysics, 643, 44-54, https://doi.org/10.1016/j.tecto.2014.12.009, 2015.

Gutiérrez-Alonso, G., Fernández-Suárez, J., López-Carmona, A., and Gärtner, A.: Exhuming a cold case: The early granodiorites of the northwest Iberian Variscan belt - A Visean magmatic flareup?, Lithosphere, 10, 194-216, https://doi.org/10.1130/L706.1, 2018.

Gutiérrez-Alonso, G., López-Carmona, A., Núñez-Guerrero, E., Martínez García, A., Fernández-Suárez, J., Pastor-Galán, D., Gutiérrez-Marco, J. C., Bernárdez, E., Colmenero, J. R., Hofmann, M., and Linnemann, U.: Neoproterozoic-Palaeozoic detrital sources in the Variscan foreland of northern Iberia: primary vs. recycled sediments. Pannotia to Pangaea: Neoproterozoic and Paleozoic Orogenic Cycles in the Circum- Atlantic Region, Geol. Soc. Lond. Spec. Publ., https://doi.org/10.1144/SP503-2020-21, in press, 2020.

Gutiérrez-Marco, J. C., Sá, A. A., García-Bellido, D. C., and Rábano, I.: The Bohemo-Iberian regional chronostratigraphical scale for the Ordovician System and palaeontological correlations within South Gondwana, Lethaia, 50, 258-295, https://doi.org/10.1111/let.12197, 2017.
Gutiérrez-Marco, J. C., Piçarra, J. M., Meireles, C. A., Cózar, P., García-Bellido, D. C., Pereira, Z., Vaz, N., Pereira, S., Lopes, G., Oliveira, J. T., Quesada, C., Zamora, S., Esteve, J., Colmenar, J., Bernárdez, E., Coronado, I., Lorenzo, S., Sá, A. A., Dias da Silva, Í., González-Clavijo, E., Díez-Montes, A., and GómezBarreiro, J.: Early Ordovician-Devonian Passive Margin Stage in the Gondwanan Units of the Iberian Massif, in: The Geology of Iberia: A Geodynamic Approach, edited by: Quesada, C. and Oliveira, J. T., 75-98, Springer International Publishing, Cham., 2019.

Hindle, D., Besson, O., and Burkhard, M.: A model of displacement and strain for arc-shaped mountain belts applied to the Jura arc, J. Struct. Geol., 22, 1285-1296, https://doi.org/10.1016/S01918141(00)00038-9, 2000.

Hirt, A. M., Lowrie, W., Julivert, M., Arboleya, M. L., Lowric, A. M. H. W., and Arboleya, M. L.: Paleomagnetic results in support of a model for the origin of the Asturian arc, Tectonophysics, 213, 321-339, 1992.

Hnat, J. S. and van der Pluijm, B. A.: Foreland signature of indenter tectonics: Insights from calcite twinning analysis in the Tennessee salient of the Southern Appalachians, USA, Lithosphere, 3, 317-327, https://doi.org/10.1130/L151.1, 2011.

Holmes, A.: A review of the continental drift hypothesis, Min. Mag., 40, 205-209, 1929.

Huang, W., Lippert, P. C., Zhang, Y., Jackson, M. J., Dekkers, M. J., Li, J., Hu, X., Zhang, B., Guo, Z., and van Hinsbergen, D. J. J. J.: Remagnetization of carbonate rocks in southern Tibet: Perspectives from rock magnetic and petrographic investigations, J. Geophys. Res.-Sol. Ea., 122, 24342456, https://doi.org/10.1002/2017JB013987, 2017.

Izquierdo-Llavall, E., Sainz, A. C., Oliva-Urcia, B., Burmester, R., Pueyo, E. L., and Housen, B.: Multi-episodic remagnetization related to deformation in the Pyrenean Internal Sierras, Geophys. J. Int., 201, 891-914, https://doi.org/10.1093/gji/ggv042, 2015.

Izquierdo-Llavall, E., Casas-Sainz, A. M., Oliva-Urcia, B., Villalaín, J. J., Pueyo, E., and Scholger, R.: Rotational Kinematics of Basement Antiformal Stacks: Paleomagnetic Study of the Western Nogueras Zone (Central Pyrenees), Tectonics, 37, 34563478, https://doi.org/10.1029/2018TC005153, 2018.

Izquierdo-Llavall, E., Ayala, C., Pueyo, E. L., Casas-Sainz, A. M., Oliva-Urcia, B., Rubio, F., Rodríguez-Pintó, A., ReyMoral, C., Mediato, J. F., and García-Crespo, J.: BasementCover Relationships and Their Along-Strike Changes in the Linking Zone (Iberian Range, Spain): A Combined Structural and Gravimetric Study, Tectonics, 38, 2934-2960, https://doi.org/10.1029/2018TC005422, 2019.

Jabaloy-Sánchez, A., Talavera, C., Gómez-Pugnaire, M. T., LópezSánchez-Vizcaíno, V., Vázquez-Vílchez, M., Rodríguez-Peces, M. J., and Evans, N. J.: U-Pb ages of detrital zircons from the Internal Betics: A key to deciphering paleogeographic provenance and tectono-stratigraphic evolution, Lithos, 318-319, 244-266, https://doi.org/10.1016/j.lithos.2018.07.026, 2018.

Jackson, M.: Diagenetic sources of stable remanence in remagnetized paleozoic cratonic carbonates: A rock magnetic study, J. Geophys. Res.-Sol. Ea., 95, 2753-2761, https://doi.org/10.1029/JB095iB03p02753, 1990.

Jacques, D., Muchez, P., and Sintubin, M.: Superimposed folding and W-Sn vein-type mineralisation in the Central Iberian Zone associated with late-Variscan oroclinal buckling: A structural 
analysis from the Regoufe area (Portugal), Tectonophysics, 742743, 66-83, https://doi.org/10.1016/j.tecto.2018.05.021, 2018a.

Jacques, D., Vieira, R., Muchez, P., and Sintubin, M.: Transpressional folding and associated cross-fold jointing controlling the geometry of post-orogenic vein-type W-Sn mineralization: examples from Minas da Panasqueira, Portugal, Miner. Deposita, 53, 171-194, https://doi.org/10.1007/s00126-017-07286, 2018b.

Johnston, S. T.: The Great Alaskan Terrane Wreck: Reconciliation of paleomagnetic and geological data in the Northern Cordillera, Earth Planet. Sc. Lett., 193, 259-272, https://doi.org/10.1016/S0012-821X(01)00516-7, 2001.

Johnston, S. T., Weil, A. B., and Gutiérrez-Alonso, G.: Oroclines: Thick and thin, GSA Bull., 125, 643-663, https://doi.org/10.1130/B30765.1, 2013.

Julivert, M.: L'évolution structurale de l'Arc Asturien, Paris, Publications de l'Institut Francais du Petrole \& Editions Technip, 1971.

Julivert, M. and Arboleya, M. L.: A geometrical and kinematical approach to the nappe structure in an arcuate fold belt: the Cantabrian nappes (Hercynian chain, NW Spain), J. Struct. Geol., 6, 499-519, https://doi.org/10.1016/01918141(84)90061-0, 1984.

Julivert, M. and Marcos, A.: superimposed folding under flexural conditions in the Cantabrian Zone (Hercynian Cordillera, Northwest Spain), Am. J. Sci., 273, 353-375, https://doi.org/10.2475/ajs.273.5.353, 1973.

Julivert, M., Fontboté, J. M., Ribeiro, A., and Nabais Conde, L. E.: Mapa Tectónico de la Península Ibérica y Baleares E: $1: 1.000 .000$ y memoria explicativa, Publ IGME, Madrid, 113, 1974.

Julivert, M., Vegas, R., Roiz, J. M., and Martinez-Rius, A.: La estructura de la extensión SE de la Zona Centroibérica con metamorfismo de bajo grado, in: Libro Jubilar JM Ríos, Geología de España, Madrid, 477-489, 1983.

Keppie, F.: How subduction broke up Pangaea with implications for the supercontinent cycle, Geol. Soc. Lond. Spec. Publ., 424, 265-288, https://doi.org/10.1144/SP424.8, 2016.

Kirsch, M., Keppie, J. D., Murphy, J. B., and Solari, L. A.: Permian-Carboniferous arc magmatism and basin evolution along the western margin of Pangea: Geochemical and geochronological evidence from the eastern Acatlan Complex, southern Mexico, Geol. Soc. Am. Bull., 124, 1607-1628, https://doi.org/10.1130/B30649.1, 2012.

Kollmeier, J. M., van der Pluijm, B. A., and Van der Voo, R.: Analysis of Variscan dynamics; early bending of the CantabriaAsturias Arc, northern Spain, Earth Planet. Sc. Lett., 181, 203216, https://doi.org/10.1016/S0012-821X(00)00203-X, 2000.

Kroner, U. and Romer, R. L. L.: Two plates - Many subduction zones: The Variscan orogeny reconsidered, Gondwana Res., 24, 298-329, https://doi.org/10.1016/j.gr.2013.03.001, 2013.

Langereis, C. G., Krijgsman, W., Muttoni, G., and Menning, M.: Magnetostratigraphy-concepts, definitions, and applications, Newsl. Stratigr., 43, 207-233, 2010.

Leite Mendes, B. D., Pastor-Galán, D., Dekkers, M., and Krijgsman, W.: Avalonia, Get Bent! Paleomagnetism from SW Iberia Confirms the Greater Cantabrian Orocline, EarthArXiv [preprint], https://doi.org/10.31223/osf.io/evwc6, 2020.
Li, P. and Rosenbaum, G.: Does the Manning Orocline exist? New structural evidence from the inner hinge of the Manning Orocline (eastern Australia), Gondwana Res., 25, 1599-1613, https://doi.org/10.1016/j.gr.2013.06.010, 2014.

Li, P., Sun, M., Rosenbaum, G., Yuan, C., Safonova, I., Cai, K., Jiang, Y., and Zhang, Y.: Geometry, kinematics and tectonic models of the Kazakhstan Orocline, Central Asian Orogenic Belt, J. Asian Earth Sci., 153, 42-56, https://doi.org/10.1016/j.jseaes.2017.07.029, 2018.

Li, P.-F., Rosenbaum, G., and Rubatto, D.: Triassic asymmetric subduction rollback in the southern New England Orogen (eastern Australia): the end of the HunterBowen Orogeny, Aust. J. Earth Sci., 59, 965-981, https://doi.org/10.1080/08120099.2012.696556, 2012.

López-Carmona, A., Abati, J., Pitra, P., and Lee, J. K. W.: Retrogressed lawsonite blueschists from the NW Iberian Massif: P-T-t constraints from thermodynamic modelling and 40Ar/39Ar geochronology, Contrib. Mineral. Petr., 167, 987987, https://doi.org/10.1007/s00410-014-0987-5, 2014.

López-Moro, F. J., López-Plaza, M., Gutiérrez-Alonso, G., Fernández-Suárez, J., López-Carmona, A., Hofmann, M., and Romer, R. L.: Crustal melting and recycling: geochronology and sources of Variscan syn-kinematic anatectic granitoids of the Tormes Dome (Central Iberian Zone). A U$\mathrm{Pb}$ LA-ICP-MS study, Int. J. Earth Sci., 107, 985-1004, https://doi.org/10.1007/s00531-017-1483-8, 2018.

Lotze, F.: Zur gliederung der Variszichen der lberischen Meseta, Geotektonísche Forschungen, 6, 78-92, 1945.

Macaya, J., González-Lodeiro, F., Martínez Catalán, J. R., and Alvarez, F.: Continuous deformation, ductile thrusting and backfolding of cover and basement in the Sierra de Guadarrama, Hercynian orogen of central Spain, Tectonophysics, 191, 291-309, https://doi.org/10.1016/0040-1951(91)90063-X, 1991.

Maffione, M., Speranza, F., and Faccenna, C.: Bending of the Bolivian orocline and growth of the central Andean plateau: Paleomagnetic and structural constraints from the Eastern Cordillera (22-24 S, NW Argentina), Tectonics, 28, TC4006, https://doi.org/10.1029/2008TC002402, 2009.

Marcos, A. and Pulgar, J. A. A.: An Approach to the tectonostratigraphic evolution of the Cantabrian foreland thrust and fold belt, Hercynian Cordillera of NW Spain, Neues Jahrb. Geol. P.-A., 163, 256-260, 1982.

Marcos, A., Pérez-Estaún, A., Martínez Catalán, J. R., and Gutiérrez-Marco, J. C.: Estratigrafía y Paleogeografía, Zona Asturoccidental-Leonesa, in: Geología de España, edited by: Vera, J. A., IGME, Madrid, 2004.

Marshak, S.: KINEMATICS OF OROCLINE AND ARC FORMATION IN THIN-SKINNED OROGENS, Tectonics, 7, 73-86, 1988.

Marshak, S.: Salients, Recesses, Arcs, Oroclines, and Syntaxes - A Review of Ideas Concerning the Formation of Map-view Curves in Fold-thrust Belts, Thrust Tecton. Hydrocarb. Syst. AAPG Mem., 82, 131-156, 2004.

Martín-Algarra, A., García-Casco, A., Gómez-Pugnaire, M. T., Jabaloy-Sánchez, A., Laborda-López, C., López SánchezVizcaíno, V., Mazzoli, S., Navas-Parejo, P., Perrone, V., Rodríguez-Cañero, R., and Sánchez-Navas, A.: Paleozoic Basement and Pre-Alpine History of the Betic Cordillera, in: The Geology of Iberia: A Geodynamic Approach, edited by: Quesada, 
C. and Oliveira, J. T., 261-305, Springer International Publishing, Cham., 2019.

Martínez Catalán, J. R.: A non-cylindrical model for the northwest Iberian allochthonous terranes and their equivalents in the Hercynian belt of Western Europe, Tectonophysics, 179, 253-272, https://doi.org/10.1016/0040-1951(90)90293-H, 1990.

Martínez Catalán, J. R.: Are the oroclines of the Variscan belt related to late Variscan strike-slip tectonics?, Terra Nova, 23, 241247, https://doi.org/10.1111/j.1365-3121.2011.01005.x, 2011.

Martínez Catalán, J. R.: The Central Iberian arc, an orocline centered in the Iberian Massif and some implications for the Variscan belt, Int. J. Earth Sci., 101, 1-16, https://doi.org/10.1007/s00531-011-0715-6, 2012.

Martínez Catalán, J. R., Rodriguez, M. P. H., Alonso, P. V., PerezEstaun, A., and Lodeiro, F. G.: Lower Paleozoic extensional tectonics in the limit between the West Asturian-Leonese and Central Iberian Zones of the Variscan Fold-Belt in NW Spain, Geol. Rundsch., 81, 545-560, https://doi.org/10.1007/BF01828614, 1992.

Martínez Catalán, J., García, F. D., Arenas, R., Abati, J., Castiñeiras, P., Cuadra, P. G., Barreiro, J. G., and Pascual, F. J. R.: Thrust and detachment systems in the Ordenes Complex (northwestern Spain): Implications for the Variscan-Appalachian geodynamics, Special Papers, Geological Society of America, 163-182, 2002.

Martínez Catalán J. R., Martínez Poyatos, D., and Bea, F.: Zona Centroibérica, in: Geología de España, edited by: Vera, J. A., IGME, 68-133, 2004a.

Martínez Catalán, J. R. M., Fernández-Suárez, J., Jenner, G. A., Belousova, E., and Montes, A.: Provenance constraints from detrital zircon U-Pb ages in the NW Iberian Massif: implications for Palaeozoic plate configuration and Variscan evolution, J. Geol. Soc., 161, 463-476, https://doi.org/10.1144/0016-764903-054, 2004b.

Martínez Catalán, J. R., Arenas, R., Abati, J., Martínez, S. S., García, F. D., Suárez, J. F., Cuadra, P. G., Castiñeiras, P., Barreiro, J. G., Montes, A. D., Clavijo, E. G., Pascual, F. J. R., Andonaegui, P., Jeffries, T. E., Alcock, J. E., Fernández, R. D., and Carmona, A. L.: A rootless suture and the loss of the roots of a mountain chain: The Variscan belt of NW Iberia, C.R. Geosci., 341, 114126, https://doi.org/10.1016/j.crte.2008.11.004, 2009.

Martínez Catalán, J. R., Rubio Pascual, F. J., Diez Montes, A., Diez Fernandez, R., Gomez Barreiro, J., Dias da Silva, I., Gonzalez Clavijo, E., Ayarza, P., and Alcock, J. E..: The late Variscan HT/LP metamorphic event in NW and Central Iberia: relationships to crustal thickening, extension, orocline development and crustal evolution, Geol. Soc. Lond. Spec. Publ., 405, 225-247, https://doi.org/10.1144/SP405.1, 2014.

Martínez Catalán, J. R., Aerden, D. G. A. M., and Carreras, J.: The "Castilian bend" of Rudolf Staub (1926): historical perspective of a forgotten orocline in Central Iberia, Swiss J. Geosci., 108, 289-303, https://doi.org/10.1007/s00015-015-0202-3, 2015.

Martínez Catalán, J. R., Gómez Barreiro, J., Dias da Silva, Í., Chichorro, M., López-Carmona, A., Castiñeiras, P., Abati, J., Andonaegui, P., Fernández-Suárez, J., González Cuadra, P., and Benítez-Pérez, J. M.: Variscan Suture Zone and Suspect Terranes in the NW Iberian Massif: Allochthonous Complexes of the Galicia-Trás os Montes Zone (NW Iberia), in: The Geology of Iberia: A Geodynamic Approach, edited by: Quesada, C. and
Oliveira, J. T., 99-130, Springer International Publishing, Cham., 2019.

McWilliams, C. K., Kunk, M. J., Wintsch, R. P., and Bish, D. L.: Determining ages of multiple muscovite-bearing foliations in phyllonites using the ${ }^{40} \mathrm{Ar} /{ }^{39} \mathrm{Ar}$ step heating method: Applications to the alleghanian orogeny in central new England, Am. J. Sci., 313, 996-1016, https://doi.org/10.2475/10.2013.02, 2013.

Meijers, M. J. M., Smith, B., Pastor-Galán, D., Degenaar, R., Sadradze, N., Adamia, S., Sahakyan, L., Avagyan, A., Sosson, M., Rolland, Y., Langereis, C. G., and Müller, C.: Progressive orocline formation in the Eastern Pontides-Lesser Caucasus, Geol. Soc. Spec. Publ., 428, https://doi.org/10.1144/SP428.8, 2017.

Mergl, M. and Zamora, S.: New and revised occurrences of rhynchonelliformean brachiopods from the middle Cambrian of the Iberian Chains, NE Spain, B. Geosci., 87, 571-586, 2012.

Merino-Tomé, O. A., Bahamonde, J. R., Colmenero, J. R., Heredia, N., Villa, E., and Farias, P.: Emplacement of the Cuera and Picos de Europa imbricate system at the core of the Iberian-Armorican arc (Cantabrian zone, north Spain): New precisions concerning the timing of arc closure, B. Geol. Soc. Am., 121, 729-751, https://doi.org/10.1130/B26366.1, 2009.

Molina Garza, R. S. and Zijderveld, J. D. A.: Paleomagnetism of Paleozoic strata, Brabant and Ardennes Massifs, Belgium: Implications of prefolding and postfolding Late Carboniferous secondary magnetizations for European apparent polar wander, J. Geophys. Res., 10, 15799-15799, https://doi.org/10.1029/96JB00325, 1996.

Montes, A. D.: La Geología del Dominio “Ollo de Sapo" en las comarcas de Sanabria y Terra do Bolo, Serie Nova Terra, 494 pp., Instituto Universitario de Geología Isidro Parga Pondal, A Coruña, 2007.

Munha, J.: Metamorphic Evolution of the South Portuguese/Pulo Do Lobo Zone, in: Pre-Mesozoic Geology of Iberia, edited by: Dallmeyer, R. D. and Garcia, E. M., 363-368, Springer, Berlin, Heidelberg, 1990.

Munha, J., Barriga, F. J. A. S., and Kerrich, R.: High ${ }^{18} \mathrm{O}$ oreforming fluids in volcanic-hosted base metal massive sulfide deposits; geologic, ${ }^{18} \mathrm{O} /{ }^{16} \mathrm{O}$, and $\mathrm{D} / \mathrm{H}$ evidence from the Iberian pyrite belt; Crandon, Wisconsin; and Blue Hill, Maine, Econ. Geol., 81, 530-552, https://doi.org/10.2113/gsecongeo.81.3.530, 1986.

Murphy, J. B., Gutierrez-Alonso, G., Fernandez-Suarez, J., and Braid, J. A.: Probing crustal and mantle lithosphere origin through Ordovician volcanic rocks along the Iberian passive margin of Gondwana, Tectonophysics, 461, 166-180, 2008.

Murphy, J. B., Quesada, C., Gutiérrez-Alonso, G., Johnston, S. T., and Weil, A.: Reconciling competing models for the tectonostratigraphic zonation of the Variscan orogen in Western Europe, Tectonophysics, 681, 209-219, 2016.

Nance, R. D., Gutiérrez-Alonso, G., Keppie, J. D., Linnemann, U., Murphy, J. B., Quesada, C., Strachan, R. A., and Woodcock, N. H.: Evolution of the Rheic Ocean, Gondwana Res., 17, 194-222, https://doi.org/10.1016/j.gr.2009.08.001, 2010.

O'Brien, T. M. and van der Pluijm, B. A.: Timing of Iapetus Ocean rifting from Ar geochronology of pseudotachylytes in the St. Lawrence rift system of southern Quebec, Geology, 40, 443-446, 2012. 
Ogg, J. G., Ogg, G. M., and Gradstein, F. M.: A concise geologic time scale: 2016, Elsevier, Amsterdam, Boston, 2016.

Oliveira, J. T., Quesada, C., Pereira, Z., Matos, J. X., Solá, A. R., Rosa, D., Albardeiro, L., Díez-Montes, A., Morais, I., Inverno, C., Rosa, C., and Relvas, J.: South Portuguese Terrane: A Continental Affinity Exotic Unit, in The Geology of Iberia: A Geodynamic Approach, edited by: Quesada, C. and Oliveira, J. T., 173-206, Springer International Publishing, Cham., 2019a.

Oliveira, J. T., González-Clavijo, E., Alonso, J., Armendáriz, M., Bahamonde, J. R., Braid, J. A., Colmenero, J. R., Dias da Silva, Í., Fernandes, P., Fernández, L. P., Gabaldón, V., Jorge, R. S., Machado, G., Marcos, A., Merino-Tomé, Ó., Moreira, N., Murphy, J. B., Pinto de Jesus, A., Quesada, C., Rodrigues, B., Rosales, I., Sanz-López, J., Suárez, A., Villa, E., Piçarra, J. M., and Pereira, Z.: Synorogenic Basins, in The Geology of Iberia: A Geodynamic Approach, edited by: Quesada, C. and Oliveira, J. T., 349-429, Springer International Publishing, Cham., 2019b.

Palero-Fernández, F. J., Martin-Izard, A., Zarzalejos Prieto, M., and Mansilla-Plaza, L.: Geological context and plumbotectonic evolution of the giant Almadén Mercury Deposit, Ore Geol. Rev., 64, 71-88, https://doi.org/10.1016/j.oregeorev.2014.06.013, 2015.

Parés, J. M. and Van der Voo, R.: Paleozoic paleomagnetism of Almaden, Spain: A cautionary note, J. Geophys. Res., 97, 93539356, https://doi.org/10.1029/91JB03073, 1992.

Parés, J. M., Van der Voo, R., Stamatakos, J., and Pérez-Estaún, A.: Remagnetizations and postfolding oroclinal rotations in the Cantabrian/Asturian arc, northern Spain, Tectonics, 13, 14611471, https://doi.org/10.1029/94TC01871, 1994.

Pastor-Galán, D., Gutiérrez-Alonso, G., Meere, P. A., and Mulchrone, K. F.: Factors affecting finite strain estimation in low-grade, low-strain clastic rocks, J. Struct. Geol., 31, 15861596, https://doi.org/10.1016/j.jsg.2009.08.005, 2009.

Pastor-Galán, D., Gutiérrez-Alonso, G., and Weil, A. B.: Orocline timing through joint analysis: Insights from the Ibero-Armorican Arc, Tectonophysics, 507, 31-46, https://doi.org/10.1016/j.tecto.2011.05.005, 2011.

Pastor-Galán, D., Gutiérrez-Alonso, G., Zulauf, G., and Zanella, F.: Analogue modeling of lithospheric-scale orocline buckling: Constraints on the evolution of the Iberian-Armorican arc, B. Geol. Soc. Am., 124, 1293-1309, https://doi.org/10.1130/B30640.1, 2012a.

Pastor-Galán, D., Gutiérrez-Alonso, G., Mulchrone, K. F., and Huerta, P.: Conical folding in the core of an orocline. A geometric analysis from the Cantabrian Arc (Variscan Belt of NW Iberia), J. Struct. Geol., 39, 210-223, https://doi.org/10.1016/j.jsg.2012.02.010, 2012b.

Pastor-Galán, D., Gutiérrez-Alonso, G., Murphy, J. B. B., Fernández-Suárez, J., Hofmann, M., and Linnemann, U.: Provenance analysis of the Paleozoic sequences of the northern Gondwana margin in NW Iberia: Passive margin to Variscan collision and orocline development, Gondwana Res., 23, 1089-1103, https://doi.org/10.1016/j.gr.2012.06.015, 2013a.

Pastor-Galán, D., Gutiérrez-Alonso, G., Fernández-Suárez, J., Murphy, J. B., and Nieto, F.: Tectonic evolution of NW Iberia during the Paleozoic inferred from the geochemical record of detrital rocks in the Cantabrian Zone, Lithos, 182-183, 221-228, https://doi.org/10.1016/j.lithos.2013.09.007, 2013b.

Pastor-Galán, D., Martín-Merino, G., and Corrochano, D.: Timing and structural evolution in the limb of an oro- cline: The Pisuerga-Carrión Unit (southern limb of the Cantabrian Orocline, NW Spain), Tectonophysics, 622, 110-121, https://doi.org/10.1016/j.tecto.2014.03.004, 2014.

Pastor-Galán, D., Ursem, B., Meere, P. A., and Langereis, C.: Extending the Cantabrian Orocline to two continents (from Gondwana to Laurussia), Paleomagnetism from South Ireland, Earth Planet. Sc. Lett., 432, 223-231, https://doi.org/10.1016/j.eps1.2015.10.019, 2015a.

Pastor-Galán, D., Groenewegen, T., Brouwer, D., Krijgsman, W., and Dekkers, M. J.: One or two oroclines in the Variscan orogen of Iberia? Implications for Pangea amalgamation, Geology, 43, 527-530, https://doi.org/10.1130/G36701.1, 2015b.

Pastor-Galán, D., Dekkers, M. J., Gutiérrez-Alonso, G., Brouwer, D., Groenewegen, T., Krijgsman, W., Fernández-Lozano, J., Yenes, M., and Álvarez-Lobato, F.: Paleomagnetism of the Central Iberian curve's putative hinge: Too many oroclines in the Iberian Variscides, Gondwana Res., 39, 96-113, https://doi.org/10.1016/j.gr.2016.06.016, 2016.

Pastor-Galán, D., Mulchrone, K. F., Koymans, M. R. , van Hinsbergen, D. J. J., and Langereis, C. G.: Bootstrapped total least squares orocline test: A robust method to quantify verticalaxis rotation patterns in orogens, with examples from the Cantabrian and Aegean oroclines, Lithosphere, 9, 499-511, https://doi.org/10.1130/L547.1, 2017a.

Pastor-Galán, D., Gutiérrez-Alonso, G., Dekkers, M. J. M. J., and Langereis, C. G.: Paleomagnetism in Extremadura (Central Iberian zone, Spain) Paleozoic rocks: extensive remagnetizations and further constraints on the extent of the Cantabrian orocline, J. Iber. Geol., 43, 583-600, https://doi.org/10.1007/s41513-0170039-x, 2017b.

Pastor-Galán, D., Pueyo, E. L., Diederen, M., García-Lasanta, C., and Langereis, C. G.: Late Paleozoic Iberian Orocline(s) and the Missing Shortening in the Core of Pangea. Paleomagnetism From the Iberian Range, Tectonics, 37, 3877-3892, https://doi.org/10.1029/2018TC004978, 2018.

Pastor-Galán, D., Nance, R. D., Murphy, J. B., and Spencer, C. J.: Supercontinents: myths, mysteries, and milestones, Geol. Soc. Lond. Spec. Publ., 470, 39-64, https://doi.org/10.1144/SP470.16, 2019a.

Pastor-Galán, D., Dias da Silva, Í. F., Groenewegen, T., and Krijgsman, W.: Tangled up in folds: tectonic significance of superimposed folding at the core of the Central Iberian curve (West Iberia), Int. Geol. Rev., 61, 240-255, https://doi.org/10.1080/00206814.2017.1422443, 2019b.

Pereira, I., Dias, R., Bento, T., and Mata, J.: Exhumation of a migmatite complex along a transpressive shear zone?: inferences from the Variscan Juzbado - Penalva do Castelo Shear Zone (Central Iberian Zone), J. Geol. Soc., 174, 1004, https://doi.org/10.1144/jgs2016-159, 2017.

Pereira, M. F., Chichorro, M., Silva, J. B., Ordóñez-Casado, B., Lee, J. K. W. W., and Williams, I. S.: Early carboniferous wrenching, exhumation of high-grade metamorphic rocks and basin instability in SW Iberia: Constraints derived from structural geology and $\mathrm{U}-\mathrm{Pb}$ and ${ }^{40} \mathrm{Ar}-{ }^{39} \mathrm{Ar}$ geochronology, Tectonophysics, 558, 28-44, https://doi.org/10.1016/j.tecto.2012.06.020, 2012.

Pereira, M. F., Díez Fernández, R., Gama, C., Hofmann, M., Gärtner, A., and Linnemann, U.: S-type granite generation and emplacement during a regional switch from extensional to contractional deformation (Central Iberian Zone, Iberian autochthonous 
domain, Variscan Orogeny), Int. J. Earth Sci., 107, 251-267, https://doi.org/10.1007/s00531-017-1488-3, 2018.

Pérez-Cáceres, I., Poyatos, D. M., Simancas, J. F., and Azor, A.: The elusive nature of the Rheic Ocean suture in SW Iberia, Tectonics, 34, 2429-2450, https://doi.org/10.1002/2015TC003947, 2015.

Pérez-Cáceres, I., Simancas, J. F., Martínez Poyatos, D., Azor, A., and González Lodeiro, F.: Oblique collision and deformation partitioning in the SW Iberian Variscides, Solid Earth, 7, 857-872, https://doi.org/10.5194/se-7-857-2016, 2016.

Pérez-Cáceres, I., Martínez Poyatos, D., Simancas, J. F., and Azor, A.: Testing the Avalonian affinity of the South Portuguese Zone and the Neoproterozoic evolution of SW Iberia through detrital zircon populations, Gondwana Res., 42, 177192, https://doi.org/10.1016/j.gr.2016.10.010, 2017.

Pérez-Cáceres, I., Martínez Poyatos, D. J., Vidal, O., Beyssac, O., Nieto, F., Simancas, J. F., Azor, A., and Bourdelle, F.: Deciphering the metamorphic evolution of the Pulo do Lobo metasedimentary domain (SW Iberian Variscides), Solid Earth, 11, 469488, https://doi.org/10.5194/se-11-469-2020, 2020.

Pérez-Estaún, A., Bastida, F., Alonso, J. L., Marquinez, J., Aller, J., Alvarezmarron, J., Marcos, A., and Pulgar, J. A.: A thinskinned tectonics model for an arcuate fold and thrust belt - the Cantabrian Zone (Variscan Ibero-Armorican Arc), Tectonics, 7, 517-537, 1988.

Pérez-Estaún, A., Bastida, F., Martínez Catalán, J. R., GutiérrezMarco, J. C., Marcos, A., and Pulgar, J.: Stratigraphy of the West Asturian-Leonese Zone, Springer, available at: https://digital. csic.es/handle/10261/30719 (last access: 6 April 2020), 1990.

Pérez-Estaún, A., Martinezcatalan, J. R., and Bastida, F.: Crustal thickening and deformation sequence in the footwall to the suture of the Variscan belt of northwest Spain, Tectonophysics, 191, 243-253, 1991.

Perroud, H., Bonhommet, N., and Ribeiro, A.: Paleomagnetism of Late Paleozoic igneous rocks from southern Portugal, Geophys. Res. Lett., 12, 45-48, https://doi.org/10.1029/GL012i001p00045, 1985.

Perroud, H., Calza, F., and Khattach, D.: Paleomagnetism of the Silurian Volcanism at Almaden, Southern Spain, J. Geophys. Res.Solid, 96, 1949-1962, https://doi.org/10.1029/90JB02226, 1991.

Pin, C., Paquette, J. L., Santos Zalduegui, J. F., and Gil Ibarguchi, J. I.: Early Devonian suprasubduction-zone ophiolite related to incipient collisional processes in the Western Variscan Belt: The Sierra de Careón unit, Ordenes Complex, Galicia, Special Papers-Geological Society of America, 57-72, 2002.

Pin, C., Fonseca, P. E., Paquette, J. L., Castro, P., and Matte, P.: The ca. 350 Ma Beja Igneous Complex: A record of transcurrent slab break-off in the Southern Iberia Variscan Belt?, Tectonophysics, 461, 356-377, 2008.

Pueyo, E. L., Mauritsch, H. J., Gawlick, H.-J., Scholger, R., and Frisch, W.: New evidence for block and thrust sheet rotations in the central northern Calcareous Alps deduced from two pervasive remagnetization events, Tectonics, 26, TC5011, https://doi.org/10.1029/2006TC001965, 2007.

Pueyo, E. L., Sussman, A. J., Oliva-Urcia, B., and Cifelli, F.: Palaeomagnetism in fold and thrust belts: Use with caution, Geol. Soc. Spec. Publ., 425, 259-276, https://doi.org/10.1144/SP425.14, 2016.

Quesada, C.: The Ossa-Morena Zone of the Iberian Massif: a tectonostratigraphic approach to its evolution, Z. Dtsch.
Ges. Geowiss., 157, 585-595, https://doi.org/10.1127/18601804/2006/0157-0585, 2006.

Quesada, C. and Dallmeyer, R. D. D.: Tectonothermal evolution of the Badajoz-Cordóba shear zone (SW Iberia): characteristics and ${ }^{40} \mathrm{Ar} /{ }^{39} \mathrm{Ar}$ mineral age constraints, Tectonophysics, 231, 195213, https://doi.org/10.1016/0040-1951(94)90130-9, 1994.

Quesada, C., Braid, J. A., Fernandes, P., Ferreira, P., Jorge, R. S., Matos, J. X., Murphy, J. B., Oliveira, J. T., Pedro, J., and Pereira, Z.: SW Iberia Variscan Suture Zone: Oceanic Affinity Units, in: The Geology of Iberia: A Geodynamic Approach, edited by: Quesada, C. and Oliveira, J. T., 131-171, Springer International Publishing, Cham., 2019.

Rankin, D. W.: Appalachian salients and recesses: Late Precambrian continental breakup and the opening of the Iapetus Ocean, J. Geophys. Res., 81, 5605-5619, https://doi.org/10.1029/JB081i032p05605, 1976.

Rezaeian, M., Kuijper, C. B., van der Boon, A., PastorGalán, D., Cotton, L. J., Langereis, C. G., and Krijgsman, W.: Post-Eocene coupled oroclines in the Talesh (NW Iran): Paleomagnetic constraints, Tectonophysics, 786, 228459, https://doi.org/10.1016/j.tecto.2020.228459, 2020.

Ribeiro, A., Munhá, J., Dias, R., Mateus, A., Pereira, E., Ribeiro, L., Fonseca, P., Araújo, A., Oliveira, T., Romão, J., Chaminé, H., Coke, C., and Pedro, J.: Geodynamic evolution of the SW Europe Variscides, Tectonics, 26, TC6009, https://doi.org/10.1029/2006TC002058, 2007.

Ries, A. C. and Shackleton, R. M.: Catazonal Complexes of North-West Spain and North Portugal, Remnants of a Hercynian Thrust Plate, Nat. Phys. Sci., 234, 65-68, https://doi.org/10.1038/physci234065a0, 1971.

Ries, A. C. and Shackleton, R. M.: Patterns of Strain Variation in Arcuate Fold Belts, Philos. T. R. Soc. S.-A, 283, 281-288, 1976

Robardet, M. and Marco, J. C. G.: The Ordoviciam, Silurian and Devonian sadimentary rocks of the Ossa-Morena Zone (SW Iberian Peninsula, Spain), Cuadernos de geología ibérica (Journal of iberian geology: an international publication of earth sciences), 30, 73-92, 2004.

Rodríguez-Cañero, R., Jabaloy-Sánchez, A., Navas-Parejo, P., Martín-Algarra, A., Rodríguez, R., Antonio, C., Sánchez, J., Navas, P., Agustín, P., and Algarra, M.: Linking Palaeozoic palaeogeography of the Betic Cordillera to the Variscan Iberian Massif?: new insight through the first conodonts of the Nevado-Filábride Complex, Int. J. Earth Sci., 107, 1791-1806, https://doi.org/10.1007/s00531-017-1572-8, 2018.

Rosenbaum, G.: Geodynamics of oroclinal bending: Insights from the Mediterranean, J. Geodyn., 82, 5-15, https://doi.org/10.1016/j.jog.2014.05.002, 2014.

Rubio Pascual, F. J., Arenas, R., Martínez Catalán, J. R., Rodríguez Fernández, L. R., and Wijbrans, J. R.: Thickening and exhumation of the Variscan roots in the Iberian Central System: Tectonothermal processes and ${ }^{40} \mathrm{Ar} /{ }^{39} \mathrm{Ar}$ ages, Tectonophysics, 587, 207-221, https://doi.org/10.1016/j.tecto.2012.10.005, 2013.

Rubio Pascual, F. J., López-Carmona, A., and Arenas, R.: Thickening vs. extension in the Variscan belt: P-T modelling in the Central Iberian autochthon, Tectonophysics, 681, 144-158, https://doi.org/10.1016/j.tecto.2016.02.033, 2016.

Sánchez-García, T., Chichorro, M., Solá, A. R., Álvaro, J. J., DíezMontes, A., Bellido, F., Ribeiro, M. L., Quesada, C., Lopes, J. C., Dias da Silva, Í., González-Clavijo, E., Gómez Barreiro, J., and 
López-Carmona, A.: The Cambrian-Early Ordovician Rift Stage in the Gondwanan Units of the Iberian Massif, in The Geology of Iberia: A Geodynamic Approach, edited by: Quesada, C. and Oliveira, J. T., 27-74, Springer International Publishing, Cham., 2019.

Schulz, G.: Descripción geológica de Asturias: Publicada de Real Órden, Con un atlas, José Gonzalez, Madrid, 1858.

Schwartz, S. Y. and Van der Voo, R.: Paleomagnetic evaluation of the Orocline hypothesis in the central and southern Appalachians, Geophys. Res. Lett., 10, 505-508, 1983.

Shaw, J. and Johnston, S. T.: Terrane wrecks (coupled oroclines) and paleomagnetic inclination anomalies, Earth-Sci. Rev., 154, 191-209, https://doi.org/10.1016/j.earscirev.2016.01.003, 2016.

Shaw, J., Johnston, S. T., Gutiérrez-Alonso, G., and Weil, A. B.: Oroclines of the Variscan orogen of Iberia: Paleocurrent analysis and paleogeographic implications, Earth Planet. Sc. Lett., 329330, 60-70, https://doi.org/10.1016/j.epsl.2012.02.014, 2012.

Shaw, J., Johnston, S. T., Gutiérrez-Alonso, G., and Pastor-Galán, D.: Provenance variability along the Early Ordovician north Gondwana margin: Paleogeographic and tectonic implications of U-Pb detrital zircon ages from the Armorican Quartzite of the Iberian Variscan belt, Bull. Geol. Soc. Am., 126, 702-719, https://doi.org/10.1130/B30935.1, 2014.

Shaw, J., Johnston, S. T., and Gutiérrez-Alonso, G.: Orocline formation at the core of Pangea: A structural study of the Cantabrian orocline, NW Iberian Massif, Lithosphere, 7, 653661, https://doi.org/10.1130/L461.1, 2015.

Shaw, J., Johnston, S. T., and Gutiérrez-Alonso, G.: Orocline formation at the core of Pangea: A structural study of the Cantabrian orocline, NW Iberian Massif, Lithosphere, 8, 97-97, https://doi.org/10.1130/L461.1, 2016.

Simancas, J. F., Carbonell, R., Lodeiro, F. G., Estaun, A., Juhlin, C., Ayarza, P., Kashubin, A., Azor, A., Poyatos, D. M., Almodovar, G. R., Pascual, E., Saez, R., and Exposito, I.: Crustal structure of the transpressional Variscan orogen of SW Iberia: SW Iberia deep seismic reflection profile (IBERSEIS), Tectonics, 22, 2525, 2003.

Simancas, J. F., Carbonell, R., Lodeiro, F. G., Estaún, A. P., Juhlin, C., Ayarza, P., Kashubin, A., Azor, A., Poyatos, D. M., Sáez, R., and Almodóvar, G. R.: Transpressional collision tectonics and mantle plume dynamics: the Variscides of southwestern Iberia, Geological Society, London, Memoirs, 32, 345-354, 2006.

Simancas, J. F., Ayarza, P., Azor, A., Carbonell, R., Martínez Poyatos, D., Pérez-Estaún, A., and González Lodeiro, F.: A seismic geotraverse across the Iberian Variscides: Orogenic shortening, collisional magmatism, and orocline development, Tectonics, 32, https://doi.org/10.1002/tect.20035, 2013.

Solís-Alulima, B. E., López-Carmona, A., Gutiérrez Alonso, G., and Álvarez Valero, A. M.: Petrologic and thermobarometric study of the Riás schists (NW Iberian Massif), Bol. Geológico Min., 130, 445-464, https://doi.org/10.21701/bolgeomin.130.3.004, 2019.

Stampfli, G. M. and Borel, G. D.: A plate tectonic model for the Paleozoic and Mesozoic constrained by dynamic plate boundaries and restored synthetic oceanic isochrons, Earth Planet. Sc. Lett., 196, 17-33, 2002.

Staub, R.: Gedanken zur Tektonik Spaniens, Prag and Leipzig, Zürich, 1926.
Stewart, S. A.: Paleomagnetic analysis of fold kinematics and implications for geological models of the Cantabrian/Asturian arc, north Spain, J. Geophys. Res.-Sol. Ea., 100, 20079-20094, https://doi.org/10.1029/95JB01482, 1995.

Suess, E.: Das Antlitz der Erde, F. Tempsky, Prag and Leipzig, available at: http://archive.org/details/dasantlitzderer02suesgoog (last access: 12 March 2020), 1892.

Tait, J. A., Bachtadse, V., and Soffel, H. C.: Eastern Variscan fold belt?: Paleomagnetic evidence for oroclinal bending, Geology, 24, 871-874, https://doi.org/10.1130/00917613(1996)024<0871:EVFBPE>2.3.CO;2, 1996.

Tauxe, L.: Essentials of Paleomagnetism, Univ. of California Press, Berkely, California, 2010.

Thomas, W. A.: Evolution of Appalachian-Ouachita Salients and Recesses from Reentrants and Promontories in the Continental Margin, Am. J. Sci., 277, 1233-1278, https://doi.org/10.2475/ajs.277.10.1233, 1977.

Thomas, W. A.: Genetic relationship of rift-stage crustal structure, terrane accretion, and foreland tectonics along the southern Appalachian-Ouachita orogen, J. Geodyn., 37, 549-563, https://doi.org/10.1016/j.jog.2004.02.020, 2004.

Tohver, E., Weil, A. B. B. B., Solum, J. G. G. G., and Hall, C. M. M. M.: Direct dating of carbonate remagnetization by ${ }^{40} \mathrm{Ar} /{ }^{39} \mathrm{Ar}$ analysis of the smectite-illite transformation, Earth Planet. Sc. Lett., 274, 524-530, https://doi.org/10.1016/j.eps1.2008.08.002, 2008.

Valladares, M. I., Barba, P., Ugidos, J. M., Colmenero, J. R., and Armenteros, I.: Upper Neoproterozoic-Lower Cambrian sedimentary successions in the Central Iberian Zone (Spain): sequence stratigraphy, petrology and chemostratigraphy. Implications for other European zones, Int. J. Earth Sci., 89, 2-20, 2000.

van der Boon, A., van Hinsbergen, D. J. J. J. J., Rezaeian, M., Gürer, D., Honarmand, M., Pastor-Galán, D., Krijgsman, W., and Langereis, C. G. G.: Quantifying Arabia-Eurasia convergence accommodated in the Greater Caucasus by paleomagnetic reconstruction, Earth Planet. Sc. Lett., 482, 454-469, https://doi.org/10.1016/j.epsl.2017.11.025, 2018.

Van der Voo, R.: Paleomagnetism, oroclines, and growth of the continental crust, GSA Today, 14, 4-9, https://doi.org/10.1130/10525173(2004)014<4:POAGOT>2.0.CO;2, 2004.

van der Voo, R., Stamatakos, J. A., and Pares, J. M.: Kinematic constraints on thrust-belt curvature from syndeformational magnetizations in the Lagos del Valle Syncline in the Cantabrian Arc, Spain, J. Geophys. Res.-Sol. Ea., 102, 10105-10119, 1997.

van Hinsbergen, D. J. J., Torsvik, T. H., Schmid, S. M., Maţenco, L. C., Maffione, M., Vissers, R. L. M., Gürer, D., and Spakman, W.: Orogenic architecture of the Mediterranean region and kinematic reconstruction of its tectonic evolution since the Triassic, Gondwana Res., 81, 79-229, https://doi.org/10.1016/j.gr.2019.07.009, 2020.

Vergés, J.: Estudio del Complejo volcáno-sedimentario del Devónico y de la estructura de la terminación oriental del sinclinal de Almadén (Ciudad Real), in: Libro Jubilar JM Rios, Tomo 3, IGME, Madrid, 215-229, 1983.

Vissers, R. L. M., van Hinsbergen, D. J. J., van der Meer, D. G., and Spakman, W.: Cretaceous slab break-off in the Pyrenees: Iberian plate kinematics in paleomagnetic and mantle reference frames, Gondwana Res., 34, 49-59, https://doi.org/10.1016/J.GR.2016.03.006, 2016. 
Weil, A., Pastor-Galán, D., Johnston, S. T., and Gutiérrez-Alonso, G.: Late/Post Variscan Orocline Formation and Widespread Magmatism, in The Geology of Iberia: A Geodynamic Approach, edited by: Quesada, C. and Oliveira, J. T., 527-542, Springer International Publishing, Cham., 2019.

Weil, A. B.: Kinematics of orocline tightening in the core of an arc: Paleomagnetic analysis of the Ponga Unit, Cantabrian Arc, northern Spain, Tectonics, 25, TC3012, https://doi.org/10.1029/2005TC001861, 2006.

Weil, A. B. and Sussman, A. J.: Classifying curved orogens based on timing relationships between structural development and vertical-axis rotations, edited by: Sussman, A. J. and Weil, A. B., Orogenic Curvature: Integrating Paleomagnetic and Structural Analyses, Vol. 383, Geological Society of America, 1-16, 2004.

Weil, A. B. and Van der Voo, R.: Insights into the mechanism for orogen-related carbonate remagnetization from growth of authigenic Fe-oxide: A scanning electron microscopy and rock magnetic study of Devonian carbonates from northern Spain, J. Geophys. Res.-Sol. Ea., 107, EPM 1-1-EPM 1-14, 2002.

Weil, A. B., Van der Voo, R., van der Pluijm, B. A., and Parés, J. M.: The formation of an orocline by multiphase deformation: a paleomagnetic investigation of the CantabriaAsturias Arc (northern Spain), J. Struct. Geol., 22, 735-756, https://doi.org/10.1016/S0191-8141(99)00188-1, 2000.

Weil, A. B., van der Voo, R., and van der Pluijm, B. A.: Oroclinal bending and evidence against the Pangea megashear: The Cantabria-Asturias arc (northern Spain), Geology, 29, 991-994, 2001.

Weil, A. B., Van der Voo, R., and Voo, R. V. D.: Insights into the mechanism for orogen-related carbonate remagnetization from growth of authigenic Fe-oxide: A scanning electron microscopy and rock magnetic study of Devonian carbonates from northern Spain, J. Geophys. Res.-Sol. Ea., 107, EPM 1-1-EPM 1-14, https://doi.org/10.1029/2001JB000200, 2002.
Weil, A. B., Yonkee, A., and Sussman, A.: Reconstructing the kinematics of thrust sheet rotation: a paleomagnetic study of Triassic redbeds from the Wyoming Salient, U.S.A., GSA Bulletin, 122, 2-23, 2010a.

Weil, A. B., Gutiérrez-Alonso, G., and Conan, J.: New time constraints on lithospheric-scale oroclinal bending of the Ibero-Armorican Arc: a palaeomagnetic study of earliest Permian rocks from Iberia, J. Geol. Soc., 167, 127-143, https://doi.org/10.1144/0016-76492009-002, 2010b.

Weil, A. B. B., Gutiérrez-Alonso, G., Johnston, S. T., and Pastor-Galán, D.: Kinematic constraints on buckling a lithospheric-scale orocline along the northern margin of Gondwana: A geologic synthesis, Tectonophysics, 582, 25-49, https://doi.org/10.1016/j.tecto.2012.10.006, 2013.

Woodcock, N. H., Soper, N. J., and Strachan, R. A.: A Rheic cause for the Acadian deformation in Europe, J. Geol. Soc., 164, 10231036, 2007.

Yenes, M., Alvarez, F., and Gutierrez-Alonso, G.: Granite emplacement in orogenic compressional conditions: the La AlbercaBejar granitic area (Spanish Central System, Variscan Iberian Belt), J. Struct. Geol., 21, 1419-1440, 1999.

Yonkee, A. and Weil, A. B.: Quantifying vertical axis rotation in curved orogens: Correlating multiple data sets with a refined weighted least squares strike test, Tectonics, 29, TC3012, https://doi.org/10.1029/2008TC002312, 2010.

Zegers, T. E., Dekkers, M. J., and Bailly, S.: Late Carboniferous to Permian remagnetization of Devonian limestones in the Ardennes: Role of temperature, fluids, and deformation, J. Geophys. Res.-Sol. Ea., 108, 2357, https://doi.org/10.1029/2002JB002213, 2003. 